$\begin{array}{ll}\text { Research Square } & \text { Preprints are preliminary reports that have not undergone peer review. } \\ \text { They should not be considered conclusive, used to inform clinical practice, } \\ \text { or referenced by the media as validated information. }\end{array}$

\title{
Geo-Environmental and Geotechnical Characterization of Municipal Solid Waste from the Selective Collection in São Paulo City, Brazil
}

Giulliana Mondelli ( $\boldsymbol{\nabla}$ g.mondelli@ufabc.edu.br)

UFABC: Universidade Federal do ABC https://orcid.org/0000-0001-9010-4353

Mariana Barbosa Juarez

UNESP: Universidade Estadual Paulista Julio de Mesquita Filho

Christiane Jacinto

UFABC: Universidade Federal do ABC

Márcio Adilson de Oliveira

UFABC: Universidade Federal do ABC

Lúcia Helena Gomes de Coelho

UFABC: Universidade Federal do ABC

Cinthia Bergamo Biancardi

UFABC: Universidade Federal do ABC

José Leonardo de Castro Faria

UFABC: Universidade Federal do ABC

Research Article

Keywords: Waste Management, Contamination, Municipal Solid Waste Characterization, Selective Collection, Material Recovery Facilities (MRFs), Shear Strength

Posted Date: December 2nd, 2021

DOI: https://doi.org/10.21203/rs.3.rs-812873/v1

License: @ (i) This work is licensed under a Creative Commons Attribution 4.0 International License. Read Full License

Version of Record: A version of this preprint was published at Environmental Science and Pollution Research on January 28th, 2022. See the published version at https://doi.org/10.1007/s11356-021-18281-w. 


\section{Abstract}

This paper presents the characterization of municipal solid waste (MSW) randomly collected from two Material Recovery Facilities in São Paulo city, before (input - recyclables) and after (output - rejects) the sorting processes. Geo-environmental and geotechnical tests were performed on shredded samples and a digestion method was applied to detect the metals $\mathrm{As}, \mathrm{Cd}, \mathrm{Cr}, \mathrm{Cu}, \mathrm{Fe}, \mathrm{Mn}, \mathrm{Ni}, \mathrm{Pb}$, and $\mathrm{Zn}$ concentrations using ICP OES. The objective was to assist future activities of integrated solid waste management and soil pollution. Results showed different particle sizes comparing the input (44.6\%) and the output MSW (75.1\%) passing through the $100 \mathrm{~mm}$ sieve. Organic matter and ash contents indicated the influence of inorganic carbon due to plastics' presence, with values varying between $6-13 \%$. The $\mathrm{pH}$ values obtained were neutral and the electrical conductivity of the MSW rejects suggested a higher amount of ions, with values above $1000 \mu \mathrm{S} / \mathrm{cm}$. Metals analyses show that $\mathrm{Cd}, \mathrm{Cu}, \mathrm{Ni}, \mathrm{Pb}$, and $\mathrm{Zn}$ are present in high concentrations, depending on the types of the materials. Standard Proctor compaction curves yielded maximum dry unit weight varying from $6.6 \mathrm{kN} / \mathrm{m}^{3}$ to $10.0 \mathrm{kN} / \mathrm{m}^{3}$ and optimum moisture contents from $20-42 \%$. Cohesion ranged from $1.3 \mathrm{kPa}$ to $31.3 \mathrm{kPa}$ and friction angle from $3.2^{\circ}$ and $42.9^{\circ}$. The results are comparable with those obtained for other countries using different MSW treatments and contribute to the data basis for MSW from the selective collection, aiming the integrated solid waste management, serving for other countries that adopt MSW sorting and recycling.

\section{Introduction}

Municipal solid wastes (MSW) have different physical, chemical, and biological properties because they are very heterogeneous about their geo-environmental and geotechnical parameters. Due to their varied origins, the consumption patterns, and the cultural, climatic, and social differences in characteristics according to their generation locality.

Considerable advances in MSW destinations are necessary. The biggest cities have been suffering from problems related to the higher quantities of materials, and the smallest ones are increasingly unable to treat their waste (Andrade and Ferreira 2011). Many technologies have been developed in recent years to solute these problems, like landfill mining, which uses the collection of minerals and solids reuse; environmental education and social policies, such as the 5 R's; ecological reform and integrated solid waste management systems, with selective collection and processing sorting facilities or mechanical-biological treatment plants, those avoid the greenhouse gases emissions (Brum and Hillig 2010; Krook et al. 2012; Calabrò et al. 2015). It is also essential to pay attention to the sanitary landfills, since if poorly designed, implanted, and operated, they can generate the same or more dangerous impacts than the irregular discharges (Oliveira and Pasqual 2004).

In Brazil, the National Solid Waste Policy (Brasil 2010) determines that only non-reusable and non-recyclable materials, also called rejects, must be sent to final disposal at appropriate sites, previously chosen through environmental, hydrogeological, geological, and geotechnical studies, as requirements for sanitary landfills projects. This Policy defines a hierarchy of actions for the solid waste destination before final disposal, aiming to reduce the amount of waste finally disposed into landfills. Firstly, is recommended no generation, followed by reduction, reuse, recycling, treatment, and finally the environmentally adequate final disposal of the rejects. Adequate characterization and destination of the MSWwhich can be treated or reused, or the rejects direct disposed of into the landfills, is, therefore, extremely important to reach sustainable solid waste management. Within all these aspects above, how should be the project of future landfills? It is thought that all geotechnical, environmental, and generation estimation parameters may change considerably, and even from region to region, depending on how they contextualize their rejects.

However, Brazil has about 29.4 million tons of MSW per year disposed of without any sanitary measures in open dumps, uncontrolled landfills, street margins, valley bottoms, and water bodies, following a pattern similar to that found in other developing countries (Gómez-Puentes et al. 2014; Abrelpe 2020). This practice can lead to problems such as contamination of water bodies, silting, flooding, a proliferation of diseases by agents, vectors, or substances (Mucelin and Bellini 2008).

According to Abrelpe (2020), the composition of the MSW collected from 186 Brazilian municipalities presents organic matter (45.3\%), plastic (16.8\%), rejects as sanitary waste, undefined materials and recyclable packaging with contamination (14.1\%), paper, and cardboard (10.4\%), textiles, leather and rubber (5.6\%), glass (2.7\%), metal (2.3\%), multilayer packaging (1.4\%) and others materials (1.4\%).

Most of the studies conducted in Brazil are focused on the total waste mass, that is, without considering the effects of selective collection and other treatments. Therefore, there is a lack of information about the specific characteristics of MSW rejects defined by the National Solid Waste Policy, assuming its implementation in the future. With the gravimetric analysis, this portion must pass through geotechnical characterization tests such as grain size distribution, dry, wet and saturated unit weight, moisture content, permeability, compaction, settlement, shear strength, added by biodegradation and mineralogical measurements over time, as studied by Wolny-Koładka et al. (2020).

The geo-environmental and geotechnical MSW characterization are important to estimate the service life of the sanitary landfills, since depending on what is considered as rejects, geomechanical and microbiological properties expected for these may be incompatible with those used today (Gomes 1989; Carvalho 1999; Abreu 2015). It is worth mentioning here the great responsibility of the stakeholders involved in the technological evolution (government agencies, public authorities, designers, educational institutions, among others), ensuring the environmental safety and sustainability principles compliance.

This paper aims to present the results of geo-environmental and geotechnical tests performed with door-to-door selective collected MSW from São Paulo city, Brazil. Aiming to know and compare the inputs and outputs of the Material Recovery Facilities (MRFs) in operation in the city, the following tests were carried out: gravimetric analyses, grain size distribution, $\mathrm{pH}$, electrical conductivity, moisture, organic matter, ash, and metals contents. Compaction and shear strength tests were carried out only on the output samples (rejects) to predict the geo-mechanical behavior of the future landfills in case of implementation of the MSW treatment hierarchy foreseen by the National Solid Waste Policy. 
These results contribute to the database regarding the characterization of MSW from the selective collection before and after screening processes serving as a reference to MSW treatment policies with similar characteristics in other countries and cities. The research hypothesis is if the geo-environmental and geotechnical characterization of the MSW from the selective collection and after sorting might change when disposed into landfills without any prior treatment in comparison with the results of mixed MSW.

\section{Materials And Methods MSW sampling}

According to Paschoalin et al. (2014), São Paulo city is responsible for the generation of about 20.1 thousand tons/day of MSW, with $35 \%$ of potential recyclables. The waste management is divided into the Southeast and Northwest regions, under the companies Ecourbis Ambiental and Loga - Logística Ambiental responsibility, respectively. Samples analyzed in this study were collected from the two Material Recovery Facilities (MRFs) located in the municipality, since they receive most of the dry items from the selective collection carried out once a week in 75 districts - about 80 tons/day each, during the sampling period, from May/2017 to May/2018. To facilitate the data comprehension, the notations MRF-Ecourbis and MRF-Loga were used. Figure 1 presents the location of the study MRFs in São Paulo City, Brazil.

Fig. 1São Paulo city and the study MRFs locations.

The mechanical sorting process occurs through the following steps: opening of the plastic bags; transporting materials to a rotating sieve for grouping by size; separating medium size items in ballistic equipment; identification of paper and plastic using optical sensors and metals with magnetic and induction sensors. Both have cooperative members responsible for inspecting and controlling the quality of the output. Each plant has a capacity of 250 tons/day, although they receive less than half of the estimated value (80 tons/day - 1600 tons/month). During the Covid-19 pandemic, practically all manual facilities closed, and only the mechanical ones, or the MRFs, did not have their activities suspended in the city. The MRF-Ecourbis sends its MSW rejects to the Central de Tratamento Leste landfill and the MRF-Loga to the Caieiras city landfill.

Sampling methodology included fourteen campaigns performed on alternating weekdays and schedules, as shown in the Supplementary Material. Only doorto-door selective collection trucks arriving at the MRFs were considered. The procedures described by ABNT NBR 10007 (2004) and MODECOM (1993) standards were adopted as a basis, aiming to incorporate a greater diversity of materials, districts with different social-economical aspects, and cultural events. Samples were collected randomly from the input $(I)$ - before $\left(I_{1}\right)$ and after $\left(I_{2}\right)$ passing through the bag breaker - and the output $(0)$ of mechanical and manual sorting processes.

\section{Gravimetric composition and grain size distribution}

The sampling process considered the amount necessary for sorting and analyzing data from the volume/weight ratio of the collected materials. For coarse sieving, steel sieves with openings of $100,75,50,37.5,25,19$, and $9.5 \mathrm{~mm}$ were assembled. For the finest materials, sieves with openings of $4.75,2,1.18,0.6$, $0.42,0.25,0.15$ and $0.075 \mathrm{~mm}$ were used. There were not fine grains enough for the sedimentation step. Before geo-environmental tests, the output groups were subdivided into the recyclable portion $\left(\mathrm{O}_{\mathrm{rec}}\right)$, and the MSW rejects itself $\left(\mathrm{O}_{\text {rej }}\right)$.

The materials were shredded in a knife mill with a final sieve of $6 \mathrm{~mm}$ opening, homogenized, and stored at $4^{\circ} \mathrm{C}$. As known, shredding and particle size to apparatus size ratio affect compression and shear strength, and such relations have not been greatly investigated (Hossain et al. 2009). Pre-treatment was also adopted by other authors to enable laboratory tests (Landva and Clark 1990; Gabr et al. 2007; Reddy et al. 2009; Bareither et al. 2012; Zhao et al. 2014; Feng et al. 2017). Volume minimization is an interesting technique to be explored since suitable areas for landfills implantation are scarce in the Metropolitan Region of São Paulo.

Figure 2 presents a flowchart with photos with each methodological step adopted for grain size distribution, gravimetric analyses, and samples treatment for storage and characterization tests.

Fig. 2 MSW samplings preparation and analysis in the laboratory.

\section{Moisture, organic matter, and ash contents}

Based on ABNT NBR 6457 (2016), the moisture content (w) was obtained by heating the shredded samples at $65^{\circ} \mathrm{C}$ for $24 \mathrm{~h}$. Organic matter (OM) test followed ABNT NBR 13600 (1996). Samples were the same used for w determination, thus continuing the drying process in a muffle furnace at $440 \pm 5^{\circ} \mathrm{C}$ for $12 \mathrm{~h}$. The procedure to establish the ash content was similar to the $\mathrm{OM}$, but burning at $550^{\circ} \mathrm{C}$. After $2 \mathrm{~h}$ the material was stored in a desiccator until reaching room temperature, weighed, and returned to the muffle for $2 \mathrm{~h}$ at the same temperature, as described by Camargo et al. (2009). Once achieved mass constancy, the weighing procedure was repeated.

\section{$\mathrm{pH}$ and electrical conductivity}

Determination of $\mathrm{pH}$ and electrical conductivity (EC) followed Camargo et al. (2009). For $\mathrm{pH}, 10 \mathrm{~g}$ of sample mixed with $50 \mathrm{~mL}$ of deionized water. Then, samples were shaken horizontally at $220 \mathrm{rpm}$ for $5 \mathrm{~min}$. After resting for $15 \mathrm{~min}$, pH values were measured. For EC, $5 \mathrm{~g}$ of sample mixed with $50 \mathrm{~mL}$ of deionized water. Then, samples were shaken horizontally at $220 \mathrm{rpm}$ for $30 \mathrm{~s}$. After resting for 30 minutes, this process was repeated five times. In the end, EC values were measured.

\section{Metals analysis}


The metal chosen to be analyzed were identified considering their frequency of occurrence, as also the local legislation and other similar studies, besides their acuteness. Therefore, Arsenic (As), Cadmium (Cd), Lead (Pb), Chrome ( $\mathrm{Cr}$ ), Copper (Cu), Iron (Fe), Manganese (Mn), Nickel (Ni), and Zinc ( $\mathrm{Zn}$ ) were assessed,

all of them mentioned in standard ABNT NBR 10004 (2004), as well as in European and North American legislation. Mercury (Hg) was not assessed, because of its volatile property.

For metals determination, Inductively Coupled Plasma Optical Emission Spectrometry (ICP OES) was used. The equipment used Argon plasma, together with the ICP Expert 2 software for obtaining the data. The wavelengths $(\lambda)$ were selected with the optimal emission for each metal to avoid major interference, resulting in quantification limits (LOQ) of: $\mathrm{As}\left(\lambda=193.696 \mathrm{~nm}, \mathrm{LOQ}=3 \mathrm{mg} \mathrm{L}{ }^{-1}\right) ; \mathrm{Cd}(\lambda=214.493 \mathrm{~nm}, \mathrm{LOQ}=0.01 \mathrm{mg} \mathrm{L}-1)$; $\mathrm{Cr}_{(}(\lambda=267.716 \mathrm{~nm}, \mathrm{LOQ}=0.01 \mathrm{mg}$ $\left.\mathrm{L}^{-1}\right) ; \mathrm{Cu}\left(\lambda=327.395 \mathrm{~nm}, \mathrm{LOQ}=0.01 \mathrm{mg} \mathrm{L}^{-1}\right) ; \mathrm{Fe}\left(\lambda=238.204 \mathrm{~nm}, \mathrm{LOQ}=0.01 \mathrm{mg} \mathrm{L}^{-1}\right) ; \mathrm{Mn}\left(\lambda=257.610 \mathrm{~nm}, \mathrm{LOQ}=0.01 \mathrm{mg} \mathrm{L}{ }^{-1}\right) ; \mathrm{Ni}(\lambda=231.604 \mathrm{~nm}, \mathrm{LOQ}=$ $\left.0.01 \mathrm{mg} \mathrm{L}^{-1}\right) ; \mathrm{Pb}\left(\lambda=220.353 \mathrm{~nm}\right.$, LOQ $=0.01 \mathrm{mg} \mathrm{L}^{-1}$; and $\mathrm{Zn}\left(\lambda=213.857 \mathrm{~nm}, \mathrm{LOQ}=0.001 \mathrm{mg} \mathrm{L}^{-1}\right)$.

For ICP OES analysis, ashes after muffle at $550^{\circ} \mathrm{C}$ were treated with nitroperchlorical digestion (Watson, 1994) to degrade the remaining organic material and disaggregate the metals present. The acid digestion aims sample mineralization to destroy the sample matrix and make the metallic elements available for further analysis. This way total amount of the chemical elements are determined, regardless of the chemical form in which it appears in the waste.

Initially, $1 \mathrm{~g}$ of sample was weighed and transferred to digestion tubes with the addition of $6 \mathrm{~mL}$ of perchloric acid and nitric acid mixture ( $2: 1 \mathrm{v} / \mathrm{v})$. Samples remained for $10 \mathrm{~h}$ in the digester block at $120^{\circ} \mathrm{C}$ until no more gas releasing. After digestion, tubes with remaining contents were transferred to a $25 \mathrm{~mL}$ flask, and volumes were adjusted with distilled water.

\section{Compaction}

Based on ABNT NBR 7182 (2016), Standard Proctor tests were performed for $\mathrm{O}_{\text {rec }}$ and $\mathrm{O}_{\text {rej }}$ samples of Campaigns 1 and 6 from both MRFs. The material was homogenized and arranged in three identical layers inside a $10 \mathrm{~mm}$ diameter mold. Each layer was compacted with $26 \mathrm{blows}$ using a $2.5 \mathrm{~kg}$ soil hammer. After weighing and volume measuring, MSW portions in duplicate were dried at $65^{\circ} \mathrm{C}$ for $24 \mathrm{~h}$.

\section{Shear strength}

Direct shear tests were performed in duplicate for $\mathrm{O}_{\text {rec }}$ and $\mathrm{O}_{\text {rej }}$ samples of Campaigns $2,3,4,5$, and 7 from both MRFs. Samples were previously compacted in a single layer inside the Standard Proctor mold and transferred to the shear box $(60 \times 60 \mathrm{~mm})$. Although the original idea was to shape the specimens in consonance with Standard Proctor tests results, for some of them this procedure was only feasible after water addition. Thus, it is not possible to ensure that the initial moisture content matches the optimum one.

According to ASTM D3080 (2011), the test was divided into two phases: consolidation and shear. Preliminary tests were carried out with Campaign 2 from MRF-Loga to observe the material's behavior and the limit of the equipment. These tests showed maximum horizontal displacement varying between 11 to 12 $\mathrm{mm}$, and the shear stress did not achieve a peak. The displacement rate of $0.3 \mathrm{~mm} / \mathrm{min}$ was selected, as also adopted by Bareither et al. (2012) and Zhao et al. (2014).

A total of 20 specimens were consolidated using normal stresses of $50 \mathrm{kPa}, 100 \mathrm{kPa}$, and $150 \mathrm{kPa}$. These values were chosen based on the material's age, supposing landfilling depths of 10 to $15 \mathrm{~m}$. The Mohr-Coulomb failure envelopes and shear strength parameters were determined for $3 \mathrm{~mm}, 6 \mathrm{~mm}$, and $9 \mathrm{~mm}$ of displacement, equivalent to $5 \%, 10 \%$, and $15 \%$ of the specimen's width, respectively.

\section{Results And Discussion}

\section{Gravimetric composition and grain size distribution}

Tables 1 and 2 present gravimetric analysis of input and output samples collected from MRF-Ecourbis and MRF-Loga, respectively. 
Table 1

Gravimetric composition (\%) of MSW samples collected from MRF-Ecourbis in São Paulo city (SP), Brazil.

\begin{tabular}{|c|c|c|c|c|c|c|c|c|c|c|c|c|c|c|c|c|c|c|}
\hline \multirow[t]{2}{*}{ Material (\%) } & \multicolumn{9}{|c|}{ Input samples } & \multicolumn{9}{|c|}{ Output samples } \\
\hline & 1 & 2 & 3 & 4 & 5 & 6 & 7 & $\begin{array}{l}\text { Avg. } \\
\text { (1) }\end{array}$ & $\begin{array}{l}S D \\
(2)\end{array}$ & 1 & 2 & 3 & 4 & 5 & 6 & 7 & $\begin{array}{l}\text { Avg. } \\
\text { (1) }\end{array}$ & $\begin{array}{l}\text { SD } \\
(2)\end{array}$ \\
\hline Paper & 5.7 & 8.2 & 12.0 & 3.0 & 15.0 & 12.5 & 14.2 & 10.1 & 4.5 & 9.9 & 0 & 1.6 & 2.4 & 5.4 & 0 & 2.6 & 3.1 & 3.5 \\
\hline Cardboard & 16.6 & 21.1 & 10.2 & 22.3 & 8.6 & 24.3 & 10.2 & 16.2 & 6.5 & 7.1 & 0 & 0 & 2.5 & 2.6 & 0.2 & 0.3 & 1.8 & 2.6 \\
\hline Aluminum & 0.2 & 0.6 & 2.6 & 0 & 3.3 & 0.1 & 2.4 & 1.3 & 1.4 & 0.2 & 0 & 0 & 0 & 1.8 & 0 & 0.2 & 0.3 & 0.7 \\
\hline $\begin{array}{l}\text { Ferrous } \\
\text { metals }\end{array}$ & 3.1 & 2.2 & 3.7 & 1.6 & 4.3 & 4.0 & 1.8 & 3.0 & 1.1 & 0.8 & 1.1 & 0.1 & 0.3 & 0 & 0 & 0 & 0.3 & 0.4 \\
\hline Tetra Pack & 7.2 & 7.1 & 6.5 & 5.7 & 2.9 & 5.9 & 3.3 & 5.5 & 1.7 & 2.1 & 5.5 & 0.7 & 1.5 & 1.8 & 3.4 & 0.9 & 2.3 & 1.7 \\
\hline Glass & 11.0 & 9.3 & 14.4 & 1.9 & 22.7 & 0 & 11.3 & 10.1 & 7.6 & 45.4 & 22.1 & 19.6 & 12.8 & 23.6 & 11.7 & 24.7 & 22.9 & 11.2 \\
\hline $\mathrm{PET}^{(3)}$ & 6.4 & 8.2 & 6.3 & 4.4 & 7.5 & 3.6 & 6.2 & 6.1 & 1.6 & 3.2 & 2.3 & 4.3 & 5.5 & 2.8 & 2.8 & 4.7 & 3.7 & 1.2 \\
\hline HDPE (4) & 5.8 & 4.8 & 14.8 & 1.0 & 8.4 & 2.1 & 7.7 & 6.4 & 4.6 & 1.6 & 0.4 & 0 & 2.3 & 0.1 & 0.7 & 0.4 & 0.8 & 0.9 \\
\hline PVC ${ }^{(5)}$ & 0 & 0 & 0 & 0 & 0 & 0 & 0 & 0 & 0.0 & 0 & 0 & 0.2 & 0 & 0 & 0.2 & 0 & 0.1 & 0.1 \\
\hline $\operatorname{LDPE}^{(6)}$ & 0.2 & 3.7 & 0.6 & 0.9 & 3.4 & 2.4 & 2.6 & 2.0 & 1.4 & 0.5 & 1.3 & 2.6 & 3.6 & 1.8 & 0.7 & 2.4 & 1.9 & 1.1 \\
\hline $\mathrm{PP}^{(7)}$ & 1.3 & 1.8 & 2.3 & 0.4 & 1.4 & 1.4 & 0.7 & 1.3 & 0.6 & 0.9 & 1.0 & 0.9 & 1.0 & 1.0 & 1.2 & 0.3 & 0.9 & 0.3 \\
\hline $\mathrm{PS}^{(8)}$ & 0 & 0 & 0.4 & 0 & 0 & 0 & 0 & 0.1 & 0.2 & 0 & 0.9 & 0.4 & 0.1 & 0 & 0 & 0 & 0.2 & 0.3 \\
\hline $\begin{array}{l}\text { Other } \\
\text { plastics }^{(9)}\end{array}$ & 5.6 & 0.8 & 0.2 & 0.4 & 0.5 & 0.9 & 0.6 & 1.3 & 1.9 & 8.5 & 5.0 & 0.2 & 0.3 & 1.1 & 0.2 & 0.1 & 2.2 & 3.3 \\
\hline $\begin{array}{l}\text { Undefined } \\
\text { plastics }^{(10)}\end{array}$ & 6.0 & 15.1 & 8.9 & 7.2 & 9.1 & 13.4 & 14.0 & 10.5 & 3.6 & 0 & 7.5 & 13.7 & 20.1 & 6.9 & 6.3 & 9.7 & 9.2 & 6.3 \\
\hline Textile & 6.2 & 1.3 & 1.8 & 18.5 & 10.8 & 2.4 & 5.7 & 6.7 & 6.2 & 2.1 & 8.4 & 0.2 & 1.2 & 0.1 & 0 & 2.5 & 2.1 & 3.0 \\
\hline Leather & 1.0 & 1.8 & 7.9 & 0 & 0 & 0 & 0 & 1.5 & 2.9 & 0 & 0 & 0 & 0 & 0 & 0 & 0 & 0 & 0.0 \\
\hline Rubber & 11.7 & 2.5 & 1.2 & 1.5 & 0 & 1.9 & 7.3 & 3.7 & 4.2 & 0 & 0 & 0 & 2.4 & 0 & 0 & 0 & 0.4 & 0.9 \\
\hline Wood & 0.4 & 0.9 & 1.1 & 0 & 0 & 0 & 0 & 0.3 & 0.5 & 0.8 & 0 & 2.9 & 0.3 & 6.1 & 0 & 0 & 1.4 & 2.3 \\
\hline Styrofoam & 4.0 & 0.7 & 0.5 & 0.2 & 1.2 & 3.0 & 1.8 & 1.6 & 1.4 & 0.5 & 2.8 & 1.7 & 1.2 & 1.6 & 0.4 & 0.5 & 1.2 & 0.9 \\
\hline Electronic & 0.5 & 0.2 & 4.5 & 1.2 & 0 & 11.0 & 3.3 & 2.9 & 3.9 & 0.1 & 0.6 & 3.0 & 8.0 & 0 & 4.0 & 0.8 & 2.4 & 2.9 \\
\hline Rejects & 7.2 & 9.4 & 0.2 & 8.5 & 0.5 & 10.8 & 5.7 & 6.0 & 4.2 & 14.1 & 41.1 & 47.7 & 34.2 & 43.0 & 67.5 & 49.7 & 42.5 & 16.2 \\
\hline Hazardous $^{(11)}$ & 0 & 0.3 & 0 & 21.2 & 0.3 & 0 & 1.3 & 3.3 & 7.9 & 2.2 & 0 & 0.1 & 0.2 & 0 & 0.5 & 0 & 0.4 & 0.8 \\
\hline
\end{tabular}

${ }^{(1)}$ Average; ${ }^{(2)}$ Standard deviation; ${ }^{(3)}$ Polyethylene terephthalate; ${ }^{(4)}$ High-density polyethylene; ${ }^{(5)}$ Polyvinyl chloride; ${ }^{(6)}$ Low-density polyethylene; ${ }^{(7)}$ Polypropylene; ${ }^{(8)}$ Polystyrene; ${ }^{(9)}$ Plastics that cannot be classified with any other typology investigated; ${ }^{(10)}$ Plastics that do not have a label indicating their typology; ${ }^{(11)}$ Batteries, lamps, and medicines. 
Table 2

Gravimetric composition (\%) of MSW samples collected from MRF-Loga in São Paulo city (SP), Brazil.

\begin{tabular}{|c|c|c|c|c|c|c|c|c|c|c|c|c|c|c|c|c|c|c|}
\hline \multirow[t]{2}{*}{ Material (\%) } & \multicolumn{9}{|c|}{ Input samples } & \multicolumn{9}{|c|}{ Output samples } \\
\hline & 1 & 2 & 3 & 4 & 5 & 6 & 7 & $\begin{array}{l}\text { Avg. } \\
\text { (1) }\end{array}$ & $S D^{(2)}$ & 1 & 2 & 3 & 4 & 5 & 6 & 7 & $\begin{array}{l}\text { Avg. } \\
\text { (1) }\end{array}$ & $S D^{(2)}$ \\
\hline Paper & 8.1 & 7.1 & 5.5 & 24.8 & 25.8 & 29.3 & 9.4 & 15.7 & 10.4 & 10.2 & 11.7 & 24.7 & 12.9 & 3.1 & 9.8 & 3.1 & 10.8 & 7.3 \\
\hline Cardboard & 33.0 & 38.2 & 28.1 & 29.4 & 26.8 & 11.3 & 20.3 & 26.7 & 8.7 & 1.4 & 1.5 & 45.5 & 17.1 & 9.4 & 0 & 7.4 & 11.8 & 16.0 \\
\hline Aluminum & 1.1 & 4.9 & 0.7 & 2.9 & 1.0 & 0 & 0.2 & 1.5 & 1.8 & 0.5 & 4.4 & 0 & 0 & 0 & 0.8 & 0 & 0.8 & 1.6 \\
\hline $\begin{array}{l}\text { Ferrous } \\
\text { metals }\end{array}$ & 8.1 & 10.6 & 0.8 & 3.4 & 1.3 & 0.8 & 0 & 3.6 & 4.1 & 0.6 & 0.8 & 0 & 0 & 0 & 0 & 0 & 0.2 & 0.3 \\
\hline Tetra Pack & 8.3 & 6.1 & 5.9 & 5.2 & 1.9 & 3.5 & 0.9 & 4.6 & 2.6 & 0 & 1.9 & 0 & 0 & 2.6 & 1.6 & 0 & 0.9 & 1.1 \\
\hline Glass & 7.5 & 3.8 & 15.4 & 16.4 & 10.9 & 9.9 & 6.6 & 10.1 & 4.6 & 26.6 & 2.9 & 10.9 & 9.9 & 3.7 & 5.0 & 2.8 & 8.8 & 8.5 \\
\hline $\mathrm{PET}^{(3)}$ & 9.0 & 4.5 & 13.4 & 4.7 & 7.7 & 4.7 & 8.6 & 7.5 & 3.2 & 6.6 & 15.6 & 0.3 & 3.0 & 1.7 & 0.7 & 1.7 & 4.2 & 5.4 \\
\hline $\operatorname{HDPE}^{(4)}$ & 4.7 & 10 & 7.0 & 3.5 & 1.3 & 1.5 & 2.4 & 4.4 & 3.2 & 20.5 & 4.5 & 0.1 & 0.3 & 4.0 & 0 & 1.2 & 4.4 & 7.4 \\
\hline $\mathrm{PVC}^{(5)}$ & 0 & 0 & 0 & 0 & 0 & 0 & 0 & 0 & 0.0 & 0 & 0 & 0 & 0 & 0 & 0 & 0 & 0 & 0.0 \\
\hline $\operatorname{LDPE}^{(6)}$ & 2.7 & 0.9 & 3.3 & 1.1 & 5.9 & 1.5 & 2.5 & 2.5 & 1.7 & 0.7 & 1.7 & 4.5 & 1.0 & 3.4 & 1.3 & 2.1 & 2.1 & 1.4 \\
\hline $\mathrm{PP}^{(7)}$ & 0.9 & 1.4 & 8.8 & 0.3 & 2.2 & 0.5 & 3.5 & 2.5 & 3.0 & 11.0 & 12.6 & 0.7 & 0.3 & 2.6 & 0.8 & 1.2 & 4.2 & 5.3 \\
\hline$P S^{(8)}$ & 0.3 & 0 & 0 & 0 & 0 & 0.4 & 0.5 & 0.2 & 0.2 & 1.0 & 1.4 & 0.4 & 0.2 & 0.7 & 0.5 & 0.6 & 0.7 & 0.4 \\
\hline $\begin{array}{l}\text { Other } \\
\text { plastics }^{(9)}\end{array}$ & 2.8 & 2.0 & 0.1 & 0.7 & 0.2 & 0.1 & 0 & 0.8 & 1.1 & 2.7 & 9.4 & 0.9 & 0.8 & 1.1 & 0.1 & 0 & 2.1 & 3.3 \\
\hline $\begin{array}{l}\text { Undefined } \\
\text { plastics }^{(10)}\end{array}$ & 1.4 & 2.1 & 1.5 & 0.6 & 8.1 & 4.0 & 21.0 & 5.5 & 7.3 & 0.8 & 1.6 & 4.5 & 16.3 & 10.9 & 14.2 & 23.3 & 10.2 & 8.4 \\
\hline Textile & 6.0 & 0.9 & 3.1 & 1.0 & 0.7 & 0 & 0.9 & 1.8 & 2.1 & 1.3 & 0 & 0.5 & 5.2 & 6.6 & 13.6 & 7.1 & 4.9 & 4.8 \\
\hline Leather & 0 & 0 & 0 & 0 & 4.6 & 0 & 0 & 0.7 & 1.7 & 0 & 0 & 0 & 0 & 0 & 0 & 0 & 0 & 0.0 \\
\hline Rubber & 0.4 & 0.6 & 0 & 0 & 0 & 0 & 0 & 0.1 & 0.3 & 2.8 & 5.8 & 0 & 0.2 & 0 & 0 & 0.2 & 1.3 & 2.2 \\
\hline Wood & 0 & 1.9 & 1.9 & 0.1 & 0 & 0 & 0 & 0.6 & 0.9 & 0.4 & 6.3 & 0 & 0 & 0 & 0 & 0 & 0.9 & 2.4 \\
\hline Styrofoam & 0.9 & 0.4 & 1.4 & 0.3 & 0.6 & 0.1 & 2.1 & 0.8 & 0.7 & 1.3 & 1.5 & 2.3 & 1.0 & 6.3 & 0.5 & 1.4 & 2.0 & 2.0 \\
\hline Electronic & 0 & 0.9 & 0 & 0 & 0 & 6.3 & 0 & 1.0 & 2.3 & 0.9 & 1.3 & 0 & 0 & 0.9 & 0 & 2.8 & 0.8 & 1.0 \\
\hline Rejects & 2.6 & 3.6 & 3.1 & 5.5 & 1.1 & 26.2 & 20.1 & 8.9 & 10.0 & 9.8 & 15.2 & 4.7 & 31.9 & 42.9 & 51.2 & 45.3 & 28.7 & 18.7 \\
\hline Hazardous $^{(11)}$ & 2.2 & 0 & 0 & 0 & 0 & 0 & 0.9 & 0.4 & 0.8 & 1.1 & 0 & 0 & 0 & 0 & 0 & 0 & 0.2 & 0.4 \\
\hline
\end{tabular}

(1) Average; (2) Standard deviation; ${ }^{(3)}$ Polyethylene terephthalate; ${ }^{(4)}$ High-density polyethylene; ${ }^{(5)}$ Polyvinyl chloride; ${ }^{(6)}$ Low-density polyethylene; ${ }^{(7)}$

Polypropylene; ${ }^{(8)}$ Polystyrene; ${ }^{(9)}$ Plastics that cannot be classified with any other typology investigated; ${ }^{(10)}$ Plastics that do not have a label indicating their typology; ${ }^{(11)}$ Batteries, lamps, and medicines.

Particle size curves obtained are exhibited in Figures 3 and 4, respectively. It is possible to note that both MRFs had a similar profile for the input and the output, with 0 samples presenting the finest particles. Observing the I samples, the variation of percentage passing through the $100.0 \mathrm{~mm}$ sieve is $43.3-57.2 \%$ for MRF-Loga and $34.1-4.7 \%$ for MRF-Ecourbis. It is also evident that the driest MSW have particles higher than $50 \mathrm{~mm}$ since the materials passing through this sieve range from $2-14 \%$. This fact shows that regardless of months, populations that supply MRFs do not change their consumption profile.

Observing 0 samples curves, there is a higher proportion of materials passing through the $100 \mathrm{~mm}$ sieve. The highest percentage accumulated was $78.3 \%$ for MRF-Loga (Campaign 1) and $90.6 \%$ for MRF-Ecourbis (Campaign 3). As expected, this result shows that the sorting process separates the waste by type, being able to change the items' size as well as break up those compacted. Campaign 3 from MRF-Loga presented an outlier behavior, which curve was similar to the I samples, attributed to the composition characterized by an expressive amount of paper and cardboard (Table 2).

\section{Moisture, organic matter, and ash contents}

Observing the results for MRF-Ecourbis and MRF-Loga in Table 3, OM and ash levels are practically the same for all samples, varying from 3.0 to $11.7 \%$, which are in the same level of magnitude detected by Gala et al. (2020), ranging from 1.0 to $11.7 \%$ post-consumer plastic film waste from mixed MSW in Spain. Such expected behavior is due to a strong relationship between OM and ash, with no more degradable organic carbon. For w, the sorting process promotes higher values in the outputs, except for Campaigns 2 and 5 from MRF-Ecourbis and Campaign 5 from MRF-Loga. This last sample presented a large amount 
of leather and paper in the input, which retains humidity (Table 2). The maximum w value (49.2\%) was detected for Orec from Campaign 6 from MRF-Loga. This sample also presented the highest MSW rejects percentage (51.2\%), justifying this result. 
Table 3

Moisture content (w), organic matter (OM), ash content, $\mathrm{pH}$, and electrical conductivity (EC) values for MSW samples from the study MRFs in São Paulo city (SP), Brazil.

\begin{tabular}{|c|c|c|c|c|c|c|c|}
\hline MRF & Campaign & Sample(1) & w (\%) & OM (\%) & ash (\%) & $\mathrm{pH}$ & $\mathrm{EC}(\mu \mathrm{S} / \mathrm{cm})$ \\
\hline Ecourbis & 1 & I & 2.2 & 8.2 & 8.3 & 8.1 & 597 \\
\hline Ecourbis & 1 & Orec & 9.5 & 9.3 & 9.4 & 7.7 & 949 \\
\hline Ecourbis & 1 & Orej & 3.6 & 6.0 & 6.0 & 8.0 & 617 \\
\hline Ecourbis & 2 & I & 2.7 & 6.9 & 7.0 & 7.8 & 680 \\
\hline Ecourbis & 2 & Orec & 1.2 & 8.5 & 8.6 & 8.0 & 2300 \\
\hline Ecourbis & 2 & Orej & 1.6 & 8.2 & 8.3 & 6.9 & 1901 \\
\hline Ecourbis & 3 & I & 2.6 & 7.8 & 7.9 & 7.9 & 1047 \\
\hline Ecourbis & 3 & Orec & 14.8 & 7.4 & 7.6 & 8.0 & 699 \\
\hline Ecourbis & 3 & Orej & 26.5 & 4.5 & 4.6 & 7.6 & 1380 \\
\hline Ecourbis & 4 & I & 1.6 & 11.6 & 11.7 & 7.8 & 684 \\
\hline Ecourbis & 4 & Orec & 24 & 7.2 & 7.2 & 7.7 & 830 \\
\hline Ecourbis & 4 & Orej & 29.1 & 5.8 & 5.9 & 7.2 & 2787 \\
\hline Ecourbis & 5 & I & 2.5 & 9.0 & 9.0 & 7.0 & 1092 \\
\hline Ecourbis & 5 & Orec & 1.7 & 3.6 & 3.6 & 6.9 & 1023 \\
\hline Ecourbis & 5 & Orej & 2.0 & 4.0 & 4.1 & 7.4 & 1124 \\
\hline Ecourbis & 6 & I & 3.7 & 10.7 & 10.7 & 6.9 & 829 \\
\hline Ecourbis & 6 & Orec & 15.9 & 8.0 & 8.7 & 7.2 & 709 \\
\hline Ecourbis & 6 & Orej & 23.5 & 3.0 & 3.1 & 7.4 & 679 \\
\hline Ecourbis & 7 & I & 2.3 & 13.6 & 13.7 & 7.8 & 806 \\
\hline Ecourbis & 7 & Orec & 1.2 & 7.1 & 7.2 & 7.5 & 794 \\
\hline Ecourbis & 7 & Orej & 8.4 & 3.4 & 3.6 & 7.6 & 782 \\
\hline Loga & 1 & I & 3.9 & 10.2 & 10.5 & 7.1 & 352 \\
\hline Loga & 1 & Orec & 12.7 & 11.6 & 11.6 & 7.9 & 726 \\
\hline Loga & 1 & Orej & 19.1 & 10.6 & 10.7 & 7.7 & 1160 \\
\hline Loga & 2 & 1 & 1.9 & 8.0 & 8.0 & 7.0 & 865 \\
\hline Loga & 2 & Orec & 3.3 & 8.8 & 8.9 & 8.1 & 309 \\
\hline Loga & 2 & Orej & 3.7 & 9.8 & 9.9 & 8.0 & 500 \\
\hline Loga & 3 & I & 1.5 & 13.8 & 13.9 & 7.5 & 309 \\
\hline Loga & 3 & Orec & 2.7 & 7.4 & 7.5 & 7.4 & 461 \\
\hline Loga & 3 & Orej & 3.3 & 11.5 & 11.5 & 6.8 & 2220 \\
\hline Loga & 4 & I & 2.4 & 9.0 & 9.1 & 6.5 & 545 \\
\hline Loga & 4 & Orec & 15.8 & 10.4 & 10.6 & 7.1 & 462 \\
\hline Loga & 4 & Orej & 26.9 & 8.6 & 8.7 & 7.3 & 1053 \\
\hline Loga & 5 & I & 17.6 & 7.1 & 7.1 & 7.5 & 1384 \\
\hline Loga & 5 & Orec & 2.8 & 7.2 & 7.3 & 7.5 & 1300 \\
\hline Loga & 5 & Orej & 6.9 & 5.2 & 5.4 & 7.4 & 1005 \\
\hline Loga & 6 & I & 2.9 & 9.6 & 8.8 & 7.4 & 763 \\
\hline
\end{tabular}

(1) I = input; Orec = output recyclables; Orej - output rejects. 


\begin{tabular}{|c|c|c|c|c|c|c|c|}
\hline MRF & Campaign & Sample ${ }^{(1)}$ & w (\%) & OM (\%) & ash (\%) & $\mathrm{pH}$ & $\mathrm{EC}(\mu \mathrm{S} / \mathrm{cm})$ \\
\hline Loga & 6 & Orec & 6.6 & 5.9 & 6.0 & 7.3 & 706 \\
\hline Loga & 6 & Orej & 49.2 & 5.4 & 5.5 & 7.4 & 921 \\
\hline Loga & 7 & I & 3.2 & 17.7 & 17.8 & 7.9 & 418 \\
\hline Loga & 7 & Orec & 2.3 & 16.2 & 16.4 & 7.7 & 547 \\
\hline Loga & 7 & Orej & 28.7 & 14.1 & 13.4 & 7.7 & 1022 \\
\hline
\end{tabular}

For the MRF-Ecourbis, the maximum w value was found for the Orec sample of Campaign 4 (29.1\%), in which a large amount of Styrofoam (20.1\%) was presented (Table 1), which can retain humidity on its pores. Minimum w was $1.2 \%$ for Orec of Campaigns 2 and 7 , with high amounts of glass ( $22.1 \%$ and $24.7 \%$, respectively) and electronic material (8.4\%) for Campaign 2. The higher values of $w$ found for rejects are following that found by Wolny-Koładka et al. (2020) for Residue Derivate from Fuel (RDF) and Undersized Fraction of MSW (UFMSW) from Poland, of $20.2 \pm 1.9$ and $35.5 \pm 2.0 \%$, respectively. For plastic film after manual sorting, Gala et al. (2020) found w ranging from 3.0 to $15.9 \%$.

$\mathrm{OM}$ and ash levels were higher for I and Orec samples, except for Campaigns 2 and 5 from MRF-Ecourbis and 2 and 3 from MRF-Loga. Again, the sorting process influenced these values since a big part of the carbon is presented in the organic form in papers, and in the inorganic form in many plastics, which were treated as recyclable material, while only a few ends up as rejects.

An expressive amount of rubber (5.8\%) and wood (6.3\%) are present in the output of Campaign 2 from MRF-Loga, in addition to some plastics such as PET, PP, and others, which can increase OM and ash (Tables 2 and 3). For the output samples of Campaign 3, paper (24.7\%) and cardboard (45.5\%) (Table 2) can also increase the $\mathrm{OM}$ content, changing the expected pattern. Therefore, the maximum values of $17.7 \%$ for $\mathrm{OM}$ and $17.8 \%$ for ash (Table 3 ) for the input of Campaign 7 presents significant amounts of rejects (20.1\%) and unidentified plastics (21\%). And about the minimums, $5.2 \%$ for OM and $5.4 \%$ for ash in Orej of Campaign 5 , which had less of these materials. Despite the presence of leather in the input of Campaign 5 (Table 2), it is not possible to make the same relation above since the quantity of the material (4.6\%) was probably not enough to change the properties studied.

For the MRF-Ecourbis, the maximum values were $13.6 \%$ for OM and $13.7 \%$ for ash for the I sample of Campaign 7 (Table 3 ), which presents significant amounts of paper (14.2\%), Styrofoam (14\%), and rejects (7\%) (Table 1). While the minimum, 3.0\% for OM and $3.1 \%$ for ash, were found in the Orec of Campaign 6, which contains $24.7 \%$ glass (Table 1). It is also worth mentioning that the second-highest value of OM and ash (11.6\% and $11.7 \%$ ) in the input of Campaign 4 , which can be justified by leather presence, representing $21.2 \%$ of the total mass.

The pH measurements are close to neutral, tending to alkalinity, following those obtained by Evangelou et al. (2016) and Wolny-Koładka et al. (2020). In general, I and Orec samples presented the highest pH values, except for Campaigns 5 and 6 from MRF-Ecourbis and for Campaign 4 from MRF-Loga. The 0 samples of Campaign 5 from MRF-Ecourbis were the only ones indicating the presence of Tetra Pack (Table 1), which has a mixed composition of cardboard, plastic, and aluminum, which may have influenced a subtle pH drop. The highest incidence of electronics in the I sample of Campaign 6 (10.8\%) may also have influenced the $\mathrm{pH}$ drop (Tables 1 and 3).

For MRF-Ecourbis, EC values varied widely between different campaigns (Table 3), not showing a standardized behavior of I or Orec/Orej samples. Such differences can be due to the larger amounts of glass in the output, Campaigns 5 and $7(23.6 \%$ and $24.7 \%$, respectively), as well as in the input ( $22.7 \%$ and $11.3 \%$, respectively) (Table 1). The Orej sample of Campaign 4 presents the highest value of EC $(2787 \mu \mathrm{S} / \mathrm{cm})$, which may be due to the highest Styrofoam level (Table 1). For MRF-Loga, except Campaigns 2 and 5, Orej samples were more conductive than I and Orec samples (Table 3). In the case of Campaign 2 , the I sample is more conductive because $10.6 \%$ of ferrous metals and $4.6 \%$ of non-ferrous metals were found (Table 2 ).

\section{Metals analysis}

Tables 4 and 5 present metals analysis converted to $\mathrm{mg} / \mathrm{kg}$ on a dry basis at $550^{\circ} \mathrm{C}$ (ash). The results were compared with the CONAMA Resolution Number 420 (Brasil, 2009) for contaminated soils prevention values since it is the only local reference for pollution index. 
Table 4

Metals concentrations (mg/kg) for MSW samples from MRF-Ecourbis in São Paulo city (SP), Brazil, where Orec is the recyclable portion and Orej is the rejects portion, and CONAMA is the default value based on the Brazilian Resolution

\begin{tabular}{|c|c|c|c|c|c|c|c|c|c|c|c|}
\hline MRF & Campaign & Sample $e^{(1)}$ & As & $\mathrm{Cd}$ & $\mathrm{Cr}$ & $\mathrm{Cu}$ & $\mathrm{Fe}$ & Mn & $\mathrm{Ni}$ & $\mathrm{Pb}$ & $\mathrm{Zn}$ \\
\hline Ecourbis & 1 & 1 & 1.16 & 0.53 & 33.4 & 6,075 & 3,001 & 200 & 10.9 & 29.1 & 847 \\
\hline Ecourbis & 1 & Orec & 2.84 & 0.50 & 18.6 & 187 & 12,452 & 92 & 11.0 & 22.5 & 505 \\
\hline Ecourbis & 1 & Orej & 2.38 & 0.39 & 19.2 & 242 & 9,791 & 101 & 14.7 & 58.2 & 290 \\
\hline Ecourbis & 2 & I & 1.50 & 0.42 & 10.5 & 24,665 & 14,694 & 326 & 8.6 & 16.6 & 503 \\
\hline Ecourbis & 2 & Orec & 1.44 & 0.65 & 19.3 & 9,672 & 3,884 & 184 & 9.7 & 218 & 2,680 \\
\hline Ecourbis & 2 & Orej & 1.12 & 3.15 & 15.7 & 10,330 & 3,970 & 85 & 21.7 & 453 & 3,314 \\
\hline Ecourbis & 3 & I & 2.11 & 0.64 & 40.1 & 21,845 & 13,911 & 269 & 18.8 & 33.2 & 1,502 \\
\hline Ecourbis & 3 & Orec & 2.11 & 4.85 & 12.1 & 1,156 & 4,685 & 64 & 14.4 & 49.2 & 1,093 \\
\hline Ecourbis & 3 & Orej & 2.14 & 2.69 & 12.0 & 198 & 9,000 & 100 & 14.0 & 20.1 & 813 \\
\hline Ecourbis & 4 & 1 & 1.87 & 0 & 23.4 & 358 & 6,902 & 351 & 13.4 & 29.3 & 910 \\
\hline Ecourbis & 4 & Orec & 1.41 & 1.31 & 182 & 179 & 3,927 & 68 & 12.9 & 625 & 280 \\
\hline Ecourbis & 4 & Orej & 1.11 & 1.00 & 39.6 & 449 & 4,305 & 80 & 11.2 & 22.5 & 504 \\
\hline Ecourbis & 5 & 1 & 2.74 & 0.69 & 69.8 & 365 & 6,061 & 675 & 12.0 & 44.6 & 410 \\
\hline Ecourbis & 5 & Orec & 0 & 0.88 & 29.7 & 6,150 & 4,413 & 3,767 & 13.5 & 74.1 & 1,568 \\
\hline Ecourbis & 5 & Orej & 1.36 & 2.26 & 29.1 & 311 & 3,825 & 337 & 10.6 & 390 & 929 \\
\hline Ecourbis & 6 & I & 3.26 & 0.65 & 75.5 & 447 & 11,013 & 864 & 19.0 & 134 & 957 \\
\hline Ecourbis & 6 & Orec & 0.93 & 0.23 & 24.1 & 59 & 8,534 & 207 & 7.5 & 15.2 & 444 \\
\hline Ecourbis & 6 & Orej & 0.93 & 4.55 & 94.0 & 38,558 & 6,052 & 141 & 38 & 677 & 770 \\
\hline Ecourbis & 7 & 1 & 4.47 & 1.68 & 76.2 & 709 & 10,240 & 1,280 & 91 & 944 & 1,305 \\
\hline Ecourbis & 7 & Orec & 0.77 & 0.76 & 22.5 & 30,285 & 6,278 & 1,123 & 187 & 1,603 & 1,998 \\
\hline Ecourbis & 7 & Orej & 0.35 & 0.50 & 10.9 & 6,287 & 3,924 & 71 & 11.4 & 347 & 263 \\
\hline CONAMA & & & 15 & 1.3 & 75 & 60 & - & - & 30 & 72 & 300 \\
\hline
\end{tabular}


Table 5

Metals concentrations ( $\mathrm{mg} / \mathrm{kg}$ ) for MSW samples from MRF-Loga in São Paulo city (SP), Brazil, where CONAMA is the default value based on the Brazilian Resolution N. 420/2009.

\begin{tabular}{|c|c|c|c|c|c|c|c|c|c|c|c|}
\hline MRF. & Campaign & Sample ${ }^{(1)}$ & As & $\mathrm{Cd}$ & $\mathrm{Cr}$ & $\mathrm{Cu}$ & $\mathrm{Fe}$ & $\mathrm{Mn}$ & $\mathrm{Ni}$ & $\mathrm{Pb}$ & $\mathrm{Zn}$ \\
\hline Loga & 1 & I & 2.2 & 2.9 & 65.6 & 298 & 10,794 & 422 & 15.5 & 194 & 807 \\
\hline Loga & 1 & Orec & 2.1 & 1.7 & 50.6 & 38,249 & 9,480 & 1,250 & 30.3 & 1,245 & 932 \\
\hline Loga & 1 & Orej & 2.1 & 1.8 & 63.1 & 39,673 & 9,672 & 1,687 & 965 & 5,454 & 127 \\
\hline Loga & 2 & I & 3.1 & 0.5 & 38.9 & 12,406 & 8,804 & 678 & 675 & 52.2 & 503 \\
\hline Loga & 2 & Orec & 2.0 & 1.8 & 39.1 & 483 & 10,177 & 171 & 13.4 & 86.3 & 476 \\
\hline Loga & 2 & Orej & 2.0 & 0.9 & 33.8 & 37,369 & 9,281 & 1,007 & 16.8 & 5,316 & 886 \\
\hline Loga & 3 & I & 2.6 & 10.8 & 36.3 & 15,521 & 11,037 & 1,456 & 46.1 & 1,356 & 1,067 \\
\hline Loga & 3 & Orec & 3.1 & 2.9 & 39.2 & 1,977 & 10,346 & 604 & 24.4 & 52.4 & 1,096 \\
\hline Loga & 3 & Orej & 1.4 & 0.8 & 37.4 & 12,735 & 47,223 & 166 & 19.8 & 45.8 & 1,647 \\
\hline Loga & 4 & I & 1.1 & 31.1 & 26.5 & 30,192 & 3,841 & 186 & 424 & 12,285 & 3,371 \\
\hline Loga & 4 & Orec & 2.8 & 1.5 & 17.2 & 1,370 & 3,100 & 71.7 & 10.2 & 108.3 & 724 \\
\hline Loga & 4 & Orej & 1.7 & 7.4 & 58.6 & 530 & 4,923 & 99.8 & 65.1 & 152.8 & 661 \\
\hline Loga & 5 & I & 1.7 & 12.1 & 211 & 28,476 & 11,068 & 754 & 61.5 & 137 & 516 \\
\hline Loga & 5 & Orec & 2.3 & 0.4 & 27.3 & 10,673 & 3,516 & 416 & 11.6 & 717 & 434 \\
\hline Loga & 5 & Orej & 2.8 & 4.0 & 73.2 & 13,978 & 12,470 & 1,499 & 35.6 & 127 & 582 \\
\hline Loga & 6 & I & 1.8 & 3.6 & 74.6 & 627 & 8,721 & 374 & 10.3 & 171.2 & 1,300 \\
\hline Loga & 6 & Orec & 10.5 & 10.5 & 61.4 & 708 & 11,238 & 1,642 & 145 & 55.6 & 1,256 \\
\hline Loga & 6 & Orej & 1.3 & 9.0 & 31.4 & 186 & 6,580 & 759 & 23.7 & 62.6 & 766 \\
\hline Loga & 7 & I & 3.5 & 0.7 & 56.3 & 478 & 1,966 & 782 & 13.6 & 121.6 & 444 \\
\hline Loga & 7 & Orec & 1.4 & 1.4 & 43.5 & 347 & 10,600 & 247 & 9.1 & 110.2 & 352 \\
\hline Loga & 7 & Orej & 2.1 & 0.9 & 38.5 & 6,874 & 8,013 & 465 & 51.9 & 149.6 & 1,269 \\
\hline \multicolumn{3}{|c|}{ CONAMA } & 15 & 1.3 & 75 & 60 & - & - & 30 & 72 & 300 \\
\hline
\end{tabular}

For the Orej sample of Campaign 6 and Orec sample of Campaign 7, high Cu concentrations were detected for the MRF-Ecourbis, 38,558 and 30,285 mg/kg, respectively. These samples presented the highest incidence of rejects, $67.5 \%$, and $49.7 \%$, respectively (Table 1 ), covering a wide variety of materials. During the tests, Cu wires were observed among the ashes of some samples. It is also evident that Cu presented the highest concentrations among other metals analyzed. Also, Cu concentrations were found in I samples from Campaigns $2(24,665 \mathrm{mg} / \mathrm{kg})$ and $3(21,845 \mathrm{mg} / \mathrm{kg})$. The first case may be due to the presence of Styrofoam, which can use copper oxide in its production (Oliveira, 2012) and, consequently, present residues of it in the final product. In Campaign 3 , the second-highest incidence of non-ferrous metals (3.7\%) was detected, where Cu fits, as well as the highest incidence of fabric (7.9\%), which can use copper-based dyes to its dyeing (Chagas 2009).

High concentrations of Cu were also detected for MRF-Loga. The highest ones were those found for Orec and Orej samples of Campaign 1 (38,249 mg/kg and $39,673 \mathrm{mg} / \mathrm{kg}$, respectively), and for Orej of Campaign 2 (37,369 mg/kg). In the latter, the highest occurrences of non-ferrous metals (4.4\%), and wood (6.3\%) were found, which may have been treated with copper oxide to prevent pests. Campaign 1 did not observe the same patterns or any other behavior, justified by the high $\mathrm{Cu}$ concentration. Except for these higher levels, the other samples with Cu concentrations varying from 186 to $709 \mathrm{mg} / \mathrm{kg}$ followed the levels verified by Wolny-Koładka et al. (2020) for refuse-derived fuel and undersized fraction from municipal solid waste samples, of $110.2 \pm 12.1$ and $371.1 \pm 62.6 \mathrm{mg} / \mathrm{kg}$, respectively.

The As concentrations are below the standard value $(15 \mathrm{mg} / \mathrm{kg})$ for all tested samples. The Cd concentrations for MRF-Ecourbis remained below default value for almost all samples, except for Orej from Campaigns 2, 3, 5, and 6, I from Campaign 7, and Orec from Campaigns 3 and 4. For MRF-Loga, almost all samples exceeded the default value. Then I sample from Campaign 4 registered the highest Cd concentration of $31.1 \mathrm{mg} / \mathrm{kg}$. Glass occurrence in I samples from MRF-Loga, and Cd compounds used as pigments for glass, which probably justifies high levels.

For $\mathrm{Cr}$, only a few samples exceeded the limit of $75 \mathrm{mg} / \mathrm{kg}$, such as samples I of the Campaigns 6 and 7 from MRF-Ecourbis and Campaign 6 from MRF-Loga, Orej of the Campaign 6 from MRF-Ecourbis and Orec for Campaigns 4 from MRF-Ecourbis, and Campaign 6 from MRF-Loga. The high value of 211 mg/kg in sample I of Campaign 5 from MRF-Loga can be due to leather, which uses Cr compounds in its manufacturing process. Comparing these data with those obtained by Gala et al. (2020) for post-consumer plastic films, As, Cd, Cu, and $\mathrm{Mn}$ concentrations are highest, and the others are in the same order of 
magnitude or variation. Compared with Wolny-Koładka et al. (2020), Cd, Cr and Zn are in the same order of magnitude, and As concentrations of the present study are lower.

All remaining metals, including Ni for MRF-Loga, except Fe and Mn which are not included in the CONAMA resolution, indicate contamination of the dry MSW ashes. Even in the absence of other comparison parameters for the Fe concentration, the concentrations of MRF-Loga were higher than for MRF-Ecourbis, but there is no relationship with gravimetry that justifies these concentrations.

According to Mor et al. (2006), MSW pollutants leaching can contaminate the surface and groundwater through discharge of metals, and percolation of other potentially toxic substances. High levels of $\mathrm{Fe}, \mathrm{Cu}, \mathrm{Zn}$, and $\mathrm{Pb}$ (above $0.3 \mathrm{mg} \mathrm{L}^{-1}$ ) were reported in the groundwater sampling stations located more than $1 \mathrm{~km}$ far from a landfill in Chennai, India (Vasanthi et al. 2008). Similar results were reported by Abd El-Salam and Abu-Zuid (2015), those highlighted the alarming concentrations of $\mathrm{Fe}\left(11 \mathrm{mg} \mathrm{L}^{-1}\right)$ and $\mathrm{Mn}\left(1.4 \mathrm{mg} \mathrm{L}^{-1}\right)$ in the groundwater in Alexandria, in Egypt, due to landfill leachate.

The main sources of heavy metals in MSW are batteries, waste electrical and electronic equipment, rubber, and other hazardous household waste such as dyes, paints, and additives in plastic and other products (Ishchenko 2019). Therefore, the knowledge of composition and leaching behaviors of heavy metals in MSW may prevent environmental contamination, especially when landfills are closed.

\section{Compaction}

Standard Proctor tests results are presented in Figure 5. For the output samples of Campaigns 1 and 6 from MRF-Ecourbis, the $Y_{d r y, m a x}$ values were $9.5 \mathrm{kN} / \mathrm{m}^{3}$ and $10.0 \mathrm{kN} / \mathrm{m}^{3}$, respectively, both for the $\mathrm{w}_{\mathrm{opt}}$ of $20 \%$. For the output samples of Campaign 1 from MRF - Loga, the $Y_{\text {dry,max }}$ was $6.2 \mathrm{kN} / \mathrm{m}^{3}$, and the $\mathrm{w}_{\mathrm{opt}}$ was $35 \%$; for Campaign 6, the values were $7.8 \mathrm{kN} / \mathrm{m}^{3}$ and $40 \%$. The higher $\mathrm{Y}_{\text {dry }}$ were obtained for MRF-Ecourbis samples and are consistent with the higher percentage of glass, almost twice the MRF-Loga samples.

The higher dry densities obtained for the MRF - Ecourbis are analogous to those reported for MSW landfilled more than 10 years ago (Gabr and Valero 1995 , Fucale 2005, Naveen, Sivapullaiah and Sitharam 2014) and are consistent with the twice percentage of glass present, in comparison with the MRF - Loga. The latter proved to be lighter, according to the dry density close to $7 \mathrm{kN} / \mathrm{m}^{3}$, as commonly adopted for landfills dimensioning.

The same trends reported by Pulat and Yukselen-Aksoy (2013) regarding paper and plastic were observed. For Campaign 6 from MRF-Loga, where paper represented approximately $10 \%$ of the gravimetric composition, the $\gamma_{\text {dry,max }}$ decreased, and the $\mathrm{w}_{\mathrm{opt}}$ increased in comparison with Campaign 6 from MRFEcourbis, where there was no paper. The same effect was observed for Campaign 1 attributed to the plastics concentration about $43 \%$ in MRF-Loga and $15 \%$ for MRF-Ecourbis. There is also a possible contribution of the percentage of textiles, that have higher individual moisture content (Carvalho 1999), with 14\% in the MRF - Loga sample and nil in the MRF - Ecourbis sample. The same effect occurred for Collections 1, attributed to the plastics portion of $43 \%$ for MRF Loga and $15 \%$ for MRF - Ecourbis.

\section{Shear strength}

During the consolidation phase of direct shear tests, all samples showed similar curves, with the primary consolidation phase completed in a few minutes. The stress-displacement response of all specimens after shearing indicated resistance increasing up to the limit of the equipment. However, the values achieved by MRF-Ecourbis were higher.

At $9 \mathrm{~mm}$ of horizontal displacement and normal stress of $150 \mathrm{kPa}$, the shear stresses of this group ranged from $95 \mathrm{kPa}$ to $145 \mathrm{kPa}$, while for Campaigns 2, 3 , 5, and 7 from MRF-Loga varied between $30 \mathrm{kPa}$ and $95 \mathrm{kPa}$. This dissimilarity can be associated with the increase in initial moisture content for MRF-Loga samples. Campaign 4 from MRF-Loga presented lower $\mathrm{w}_{\text {initial, }}$, and shear stresses were $131 \mathrm{kPa}$ and $141 \mathrm{kPa}$. The gravimetric composition of this sample indicated $10 \%$ of glass, $22 \%$ of plastic, and $32 \%$ of rejects. These characteristics are similar to the amounts of the MRF-Ecourbis samples and different of the other samples of the MRF-Loga, such as Campaigns 5 and 7, with approximately $44 \%$ of rejects and $3 \%$ of glass; and Campaigns 2 and 3 with $15 \%$ and $5 \%$ of rejects, respectively (Tables 1 and 2).

Table 6 summarizes the $\gamma_{d r y}$ and $w_{\text {initial }}$ (average of three tests performed) of specimens and shear strength parameters determined at $9 \mathrm{~mm}$ or $15 \%$ displacement. Significant differences between c values obtained for Campaigns 3 and 5 from MRF-Ecourbis and 2, 4, and 7 from MRF-Loga can be noticed. These increases may indicate "cohesion due to fiber reinforcement effect", but the displacements achieved were relatively low, perhaps insufficient for the mobilization of tensile forces (Kolsch 1995). 
Table 6

Summary of the direct shear results for shredded MSW samples from both MRFs in São Paulo city (SP), Brazil.

\begin{tabular}{|c|c|c|c|c|c|c|c|}
\hline MRF & Campaign & Sample ${ }^{(1)}$ & Test & $Y_{d r y}(\%)(2)$ & $w(\%){ }^{(3)}$ & $c(\mathrm{kPa})^{(4)}$ & $\varphi\left(^{\circ}\right)^{(5)}$ \\
\hline Ecourbis & 2 & Orec + Orej & 1 & 8.3 & 63 & 8.7 & 36.1 \\
\hline Ecourbis & 2 & Orec + Orej & 2 & 8.0 & 68 & 7.0 & 38.5 \\
\hline Ecourbis & 3 & Orec + Orej & 1 & 9.8 & 40 & 7.1 & 35.1 \\
\hline Ecourbis & 3 & Orec + Orej & 2 & 9.6 & 44 & 20.7 & 36.3 \\
\hline Ecourbis & 4 & Orec + Orej & 1 & 8.9 & 53 & 31.3 & 24.8 \\
\hline Ecourbis & 4 & Orec + Orej & 2 & 9.3 & 51 & 28.4 & 26.7 \\
\hline Ecourbis & 5 & Orec + Orej & 1 & 10.2 & 49 & 12.2 & 34.6 \\
\hline Ecourbis & 5 & Orec + Orej & 2 & 9.7 & 53 & 1.3 & 42.9 \\
\hline Ecourbis & 7 & Orec + Orej & 1 & 9.9 & 41 & 18.2 & 34.0 \\
\hline Ecourbis & 7 & Orec + Orej & 2 & 9.3 & 41 & 6.0 & 41.8 \\
\hline Loga & 2 & Orec + Orej & 1 & 4.5 & 92 & 8.9 & 23.0 \\
\hline Loga & 2 & Orec + Orej & 2 & 4.2 & 82 & 15.2 & 15.0 \\
\hline Loga & 3 & Orec + Orej & 1 & 3.8 & 148 & 23.1 & 7.4 \\
\hline Loga & 3 & Orec + Orej & 2 & 3.6 & 139 & 22.0 & 3.2 \\
\hline Loga & 4 & Orec + Orej & 1 & 8.7 & 45 & 3.9 & 40.2 \\
\hline Loga & 4 & Orec + Orej & 2 & 8.7 & 49 & 26.1 & 36.8 \\
\hline Loga & 5 & Orec + Orej & 1 & 5.2 & 107 & 12.3 & 18.8 \\
\hline Loga & 5 & Orec + Orej & 2 & 5.3 & 103 & 17.7 & 22.0 \\
\hline Loga & 7 & Orec + Orej & 1 & 5.5 & 104 & 21.9 & 25.8 \\
\hline Loga & 7 & Orec + Orej & 2 & 5.6 & 109 & 18.4 & 25.2 \\
\hline
\end{tabular}

The results obtained agree with the predicted ranges for shredded MSW, from $1.3 \mathrm{kPa}$ to $31.3 \mathrm{kPa}$ for $\mathrm{c}$ and $3.2^{\circ}$ to $42.9^{\circ}$ for $\varphi$, as shown in the scatter plot of Figure 6. The exception is Campaign 3 from MRF-Loga, predominantly composed of paper and cardboard. For this sample, which specimens were molded with $w_{\text {initial }}$ above $130 \%$ to facilitate transfer from the Proctor cylinder to the shear box, the $\varphi$ values were less than $10^{\circ}$. The lowest $Y_{\text {dry }}$ and highest $w_{\text {initial }}$ belong to the campaigns from MRF-Loga which gravimetric composition was quite different from MRF-Ecourbis, containing higher percentages of paper, cardboard, and textile and lower percentages of glass.

In general, the results of geotechnical tests presented good compatibility with the results obtained without shredding or even without coming from the selective collection and can extrapolate for use in other countries. The results of geo-environmental tests indistinctly show a strong dependence on the materials present in the MSW, indicating the need for gravimetric analysis on a case-by-case basis.

\section{Conclusion}

Brazilian National Solid Waste Policy brought objectives to improve the MSW treatment and final disposal technologies as well as skills for characterization and development of procedures to reach the sustainable landfilling concept. There is a long way to achieve them in Brazil since the most basic aspects of the law were not in operation yet. One example is the definition of specific procedures for MSW, which so far does not exist. The present methodology adopted was adapted from tests elaborated for soils and sediments and was satisfactory since results were comparable with those used by other countries.

Moisture content tends to be higher for the MSW rejects and OM and ash for inputs and recyclables materials. Samples $\mathrm{pH}$ ranged from neutral to slightly alkaline and EC values higher for Orej samples. MSW geo-environmental properties from the selective collection were influenced by the sorting process because several patterns were found, depending on the types of the materials and according to the sample stage analyzed. This is the case of $\mathrm{w}$, OM, ash, and the most of tested metals, but with different effects in each parameter. These data highlights the relevance of this study since it enables the comprehension of expected behaviors of waste to be disposed into sanitary landfills. High metals concentration occurred due to dried and burned MSW, which reduced the mass and eliminated much of the OM, leaving only ashes and concentrating metals. The higher presence of glass also influenced metals concentrations of MRFEcourbis, which were lower than MRF-Loga.

The CONAMA Resolution did not have a direct practical effect on the sanitary landfill's designs, but possibly to bring up important discussions regarding MSW risky after their burning, as well as showing problems due to incorrect ashes disposal since these metals might be released into the environment causing soil 
contamination and mainly health problems. From the perspectives of this study, a more detailed analysis of each metal source using gravimetric would help clarify their presence in the waste.

Concluding, the dimensions of waste considered as rejects decrease after the sorting process. Compaction curves presented no clear peak and metals concentrations, and shear strength parameters are more susceptible to specimens composition and moisture content than the selective collection followed by the sorting process involved. The small-scale direct shear testing program indicated cohesion ranging from $1.3 \mathrm{kPa}$ to $31.3 \mathrm{kPa}$ and friction angle from $3.2^{\circ}$ to $42.9^{\circ}$, both of them similar to results found in the literature for MSW in general.

Finally, the presented geo-environmental and geotechnical characterization of the dry MSW of the São Paulo city also contributes to the next steps of the integrated solid waste management, allowing the estimative of parameters to design the intermediate treatment processes, like the home, mechanical and manual sorting processes themselves and the biological and thermal plants implementation, and also serving as an example for MSW from other regions.

\section{Declarations}

Ethics approval and consent to participate Not applicable.

Consent for publication All authors mutually agreed to publish the work in this journal.

Availability of data and materials The datasets used and/or analyzed during the current study are available from the corresponding author on reasonable request.

Competing interests The authors declare that they have no conflict of interests.

Funding FAPESP (Process 2016/08978-8), CNPq (Process 310179/2019-0) and UFABC (Process 23006.000123/2018-23).

Authors' contributions Draft and original manuscripts were written by GM, LHGC, and MBJ, and structured by GM, that coordinated the project. Investigation including Material and Methods, and Results were carried out by MBJ, CJ, MAO, CBB, and JLCF, as part of their master's and undergraduate's degrees projects at the Federal University of ABC. LHGC enabled the performance of the ICP tests as well as the tests execution and interpretation of the results.

Acknowledgments FAPESP (São Paulo State Research Foundation), CNPq (Brazilian National Council for Scientific and Technological Development), Multiuser Center at UFABC (Federal University of ABC), and AMLURB (Municipal Authority of Urban Cleaning).

\section{References}

1. Abd El-Salam MM, Abu-Zuid GI (2015) Impact of landfill leachate on the groundwater quality: a case study in Egypt. J Adv Res 6(4):579-886. https://doi.org/10.1016/j.jare.2014.02.003

2. ABNT (1996) NBR 13600: Soil - Determination of organic matter content by igniting at $440^{\circ} \mathrm{C}$ - Method of test, Associação Brasileira de Normas Técnicas, Rio de Janeiro, Brazil (in Portuguese)

3. ABNT (2004) NBR 10004: Solid waste - Classification, Associação Brasileira de Normas Técnicas, Rio de Janeiro, Brazil (in Portuguese)

4. ABNT (2004) NBR 10007: Sampling of solid waste, Associação Brasileira de Normas Técnicas, Rio de Janeiro, Brazil (in Portuguese)

5. ABNT (2016) NBR 6457: Soil samples - Preparation for compactation and characterization tests. Associação Brasileira de Normas Técnicas, Rio de Janeiro, Brazil. (in Portuguese)

6. ABNT (2016) NBR 7182: Soil - Compaction test, Associação Brasileira de Normas Técnicas, Rio de Janeiro, Brazil (in Portuguese)

7. ABRELPE (2020) Panorama dos Resíduos Sólidos no Brasil - 2020, Associação Brasileira de Empresas de Limpeza Pública e Resíduos Especiais (in Portuguese). https://abrelpe.org.br/panorama/. Accessed 04 November 2021

8. Abreu AES (2015) Geophysical investigation and shear strength of municipal solid wastes with different landfilling ages. Dissertation, Universidade de São Paulo, São Carlos, Brazil (in Portuguese)

9. Andrade RM, Ferreira JA (2011) A gestão de resíduos sólidos urbanos no Brasil frente às questões da globalização. Revista Eletrônica do Prodema 6(1):722 (in Portuguese). http://www.revistarede.ufc.br/rede/article/view/118. Accessed 04 November 2021

10. ASTM Standard D3080/D3080M-11 (2011) Standard test method for the direct shear test of soils under consolidated drained conditions. ASTM International, West Conshohocken, PA, USA

11. Bareither CA, Benson CH, Edil TB (2012) Effects of waste composition and decomposition on the shear strength of municipal solid waste. J Geotech Geoenviron Eng 138(10):1161-1174. https://doi.org/10.1061/(ASCE)GT.1943-5606.0000702

12. Brasil (2009) Resolução do Conselho Nacional do Meio Ambiente $n^{\circ} 420 / 2009$

13. Brasil (2010) Lei n 12.305/2010. Política Nacional de Resíduos Sólidos

14. Brum ABN, Hilling C (2010) Repensando o consumismo: uma reflexão sobre a necessidade de um consumo responsável. Revista Eletrônica em Gestão, Educação e Tecnologia Ambiental 1(1):115-128 (in Portuguese). https://periodicos.ufsm.br/reget/article/viewFile/2300/1400. Accessed 04 November 2021

15. Calabrò PS, Gori M, Lubello C (2015) European trends in greenhouse gases emissions from integrated solid waste management. Environ Technol 36(16):2125-2137. https://doi.org/10.1080/09593330.2015.1022230

Page $14 / 20$ 
16. Camargo OA, Moniz AC, Jorge JA, Valadares JMAS (2009) Métodos de análise química, mineralógica e física de solos do Instituto Agronômico de Campinas. Instituto Agronômico (in Portuguese)

http://www.iac.sp.gov.br/produtoseservicos/analisedosolo/docs/Boletim_Tecnico_106_rev_atual_2009.pdf. Accessed 04 November 2021

17. Carvalho MF (1999) Mechanical behavior of urban solid waste. Dissertation, Universidade de São Paulo, São Carlos, Brazil (in Portuguese)

18. Chagas MA (2009) Tratamento de efluente têxtil por processos físico-químico e biológico. Dissertation, Universidade Federal de Pernambuco, Recife, Brazil (in Portuguese)

19. Evangelou A, Calabrò PS, Greco R, Sánchez A, Komilis D (2016) Biodegradation activity of eight organic substrates: A correlation study of different test methods. Waste Biomass Valorization 7:1067-1080. https://doi.org/10.1007/s12649-016-9532-2

20. Feng S, Gao K, Chen Y, Li Y, Zhang LM, Chen HX (2017) Geotechnical properties of municipal solid waste at Laogang Landfill, China. Waste Manag 63:354-365. https://doi.org/10.1016/j.wasman.2016.09.016

21. Fucale SP (2005) Influência dos componentes de reforço na resistência de resíduos sólidos urbanos. Thesis, Universidade Federal de Pernambuco, Recife, Brazil (in Portuguese)

22. Gabr MA, Hossain MS, Barlaz MA (2007) Shear strength parameters of municipal solid waste with leachate recirculation. J Geotech Geoenviron Eng 133(4):478-484. https://doi.org/10.1061/(ASCE)1090-0241(2007)133:4(478)

23. Gabr MA, Valero SN (1995) Geotechnical properties of municipal solid waste. Geotech Test J 18(2):241-251. https://www.astm.org/DIGITAL_LIBRARY/JOURNALS/GEOTECH/PAGES/GTJ10324J.htm

24. Gala A, Guerrero M, Serra JM (2020) Characterization of post-consumer plastic film waste from mixed MSW in Spain: A key point for the successful implementation of sustainable plastic waste management strategies. Waste Manag 111:22-33. https://doi.org/10.1016/j.wasman.2020.05.019

25. Gomes LP (1989) Estudo da caracterização física e da biodegradabilidade dos resíduos sólidos urbanos em aterros sanitários. Dissertation, Universidade de São Paulo, São Carlos, Brazil (in Portuguese)

26. Gómez-Puentes FJ, Reyes-López JA, López DL, Carreón-Diazconti C, Belmonte-Jiménez S (2014) Geochemical processes controlling the groundwater transport of contaminants released by a dump in an arid region of México. Environ Earth Sci 71:609-621. https://doi.org/10.1007/s12665-013-2456-2

27. Hossain MS, Gabr MA, Asce F (2009) The effect of shredding and test apparatus size on compressibility and strength parameters of degraded municipal solid waste. Waste Manag 29(9):2417-2424. https://doi.org/10.1016/j.wasman.2009.03.024

28. Ishchenko V (2019) Heavy metals in municipal waste: the content and leaching ability by a waste fraction. Journal of Environmental Science and Health 54(14):1448-1456. https://doi.org/10.1080/10934529.2019.1655369

29. Kolsch F (1995) Material values for some mechanical properties of domestic waste. In: Proceedings of the 5th International Landfill Symposium. CISA, Cagliary, Italy, 2, pp 711-729

30. Krook J, Svensson N, Eklund M (2012) Landfill mining: A critical review of two decades of research. Waste Manag 32:513-520. https://doi.org/10.1016/j.wasman.2011.10.015

31. Landva AO, Clark JI (1990) Geotechnics of Waste Fill.. In: In: Landva A, Knowles GD (eds) Geotechnics of Waste Fills - Theory and practice. ASTM International, West Conshohocken, PA, USA. https://doi.org/10.1520/STP25301S

32. MODECOM (1993) Méthode de Caractérisation des Ordures Ménagères. ADEME, France. (in French)

33. Mor S, Ravindra K, Dahiva RP, Chandra A (2006) Leachate characterization and assessment of groundwater pollution near a municipal solid waste landfill site. Environ Monit Assess 118:435-456. https://link.springer.com/article/10.1007\%2Fs10661-006-1505-7

34. Mucelin CA, Bellini M (2008) Garbage and perceptible environmental impacts in an urban ecosystem. Soc Nat 20(1):111-124. (in Portuguese) https://doi.org/10.1590/S1982-45132008000100008

35. Naveen BP, Sivapullaiah PV, Sitharam TG (2014) Compressibility and shear strength of dumped municipal solid waste. Journal of Solid Waste Technology and Management 40(4):327-334. https://www.ingentaconnect.com/content/jswt/jswt/2014/00000040/00000004/art00004

36. Oliveira S, Pasqual A (2004) Evaluation of indicative parameters of pollution for liquid effluent of a sanitary landfill. Eng Sanit Ambient 9(3):240-249. https://doi.org/10.1590/S1413-41522004000300010

37. Oliveira SJ (2012) Obtenção de catalisadores de óxidos de ferro contendo magnésio para a síntese de estireno. Dissertation, Universidade Federal da Bahia, Salvador, Brazil (in Portuguese)

38. Paschoalin Filho JA, Silveira FF, Luz EG, Oliveira RB (2014) Comparison between the masses of urban solid waste collected in São Paulo city by means of selective and household collection. Revista de Gestão Ambiental e Sustentabilidade 3(3):19-33. (in Portuguese) http://dx.doi.org/10.5585/geas.v3i3.208

39. Pulat HF, Yukseen-Aksoy Y (2013) Compaction behavior of synthetic and natural MSW samples in different compositions. Waste Manag Res 31(12):1255-1261. https://doi.org/10.1177/0734242X13507967

40. Reddy K, Hettiarachchi H, Parakalla NS, Gangathulasi J, Bogner JE (2009) Geotechnical properties of fresh municipal solid waste at Orchard Hills Landfill. Waste Manag 29:952-959. https://doi.org/10.1016/j.wasman.2008.05.011

41. Vasanthi P, Kaliappan R, Srinivasaraghavan S (2008) Impact of poor solid waste management on groundwater. Environ Monit Assess 143:227-238. https://doi.org/10.1007/s10661-007-9971-0

42. Watson TP (1994) Analytical methods for determination of trace metals and other elements. Official and standard methods of analysis. McGraw-Hill, New York, pp 446-471

43. Wolny-Koładka K, Malinowski M, Żukowski W (2020) Impact of calcium oxide on hygienization and self-heating prevention of biologically contaminated polymer materials. Materials 13(18):4012. https://doi.org/10.3390/ma13184012

Page $15 / 20$ 
Figures

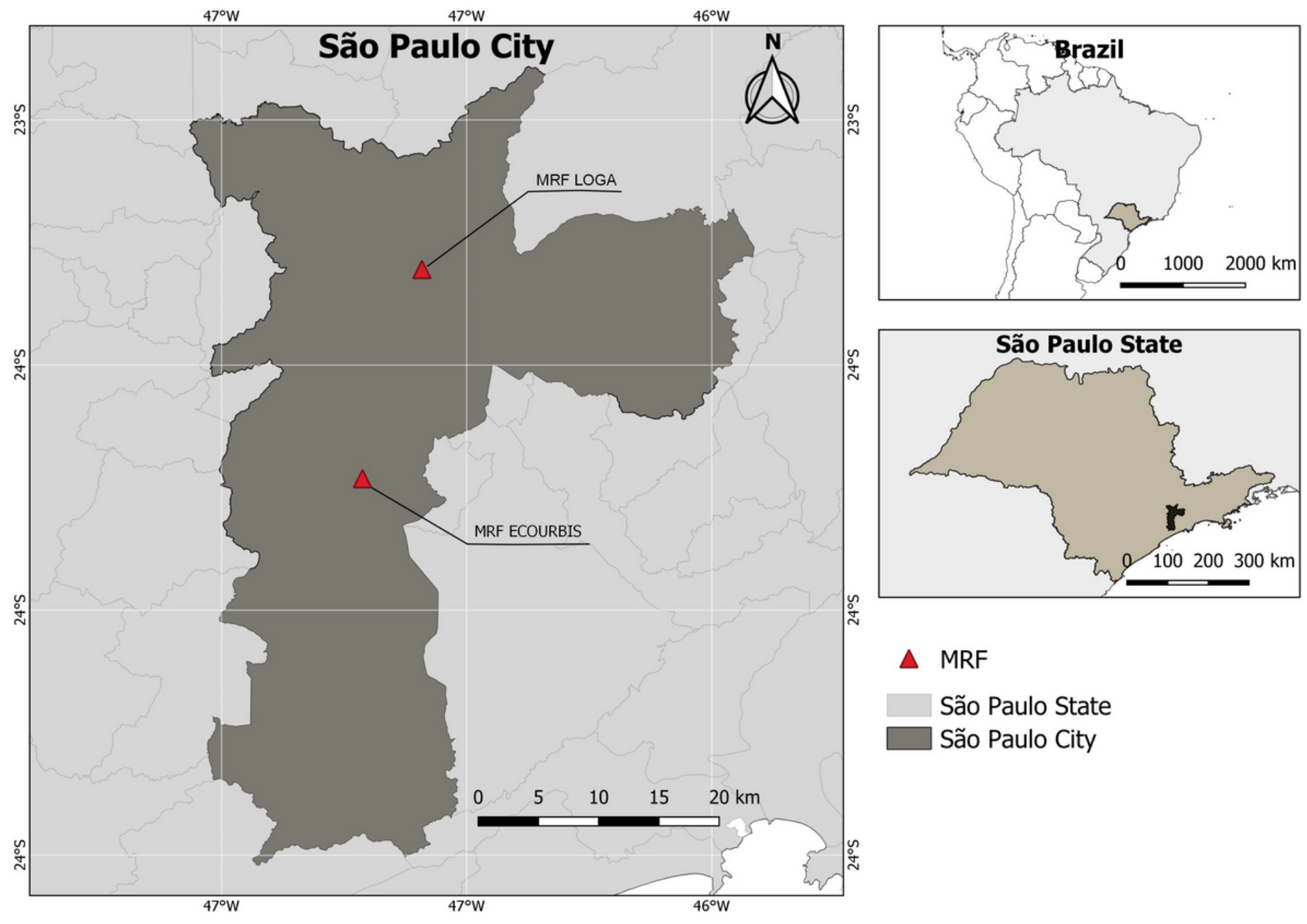

Figure 1

São Paulo city and the study MRFs locations. 


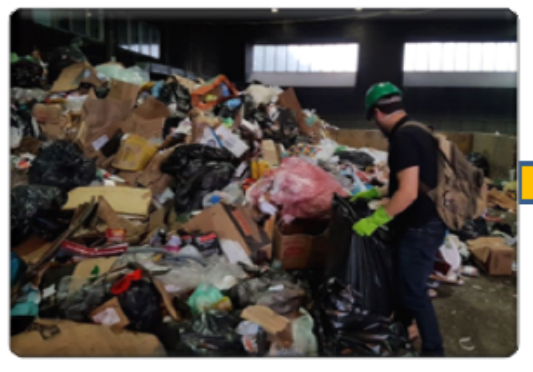

1. Input sampling

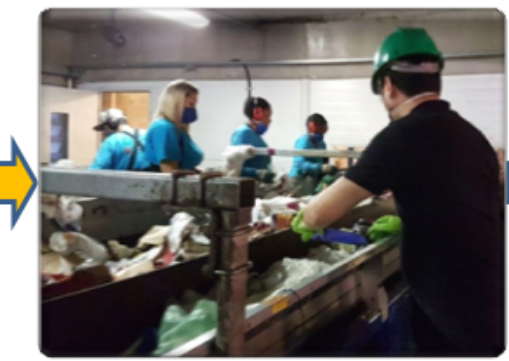

2. Output sampling

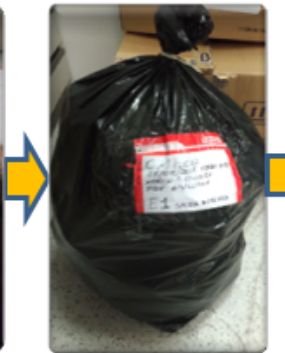

3. Labeling

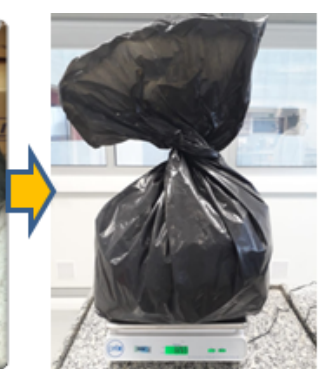

4. Initial Weighing

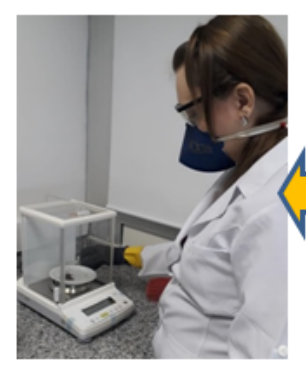

9. Fines weighing

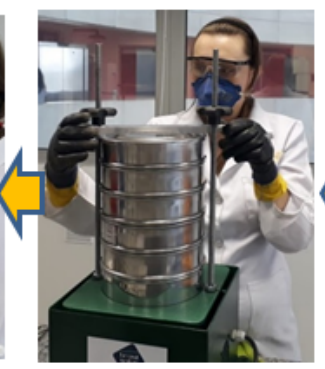

8. Fines sieving

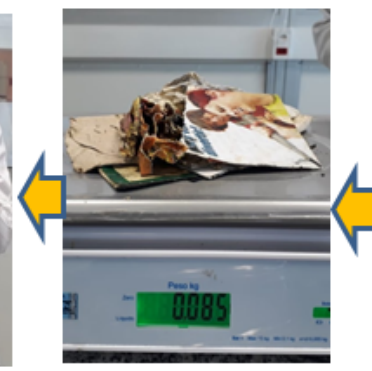

7. Coarse weighing

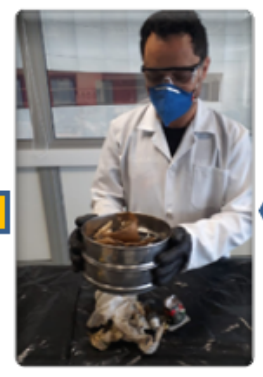

6. Coarse sieving

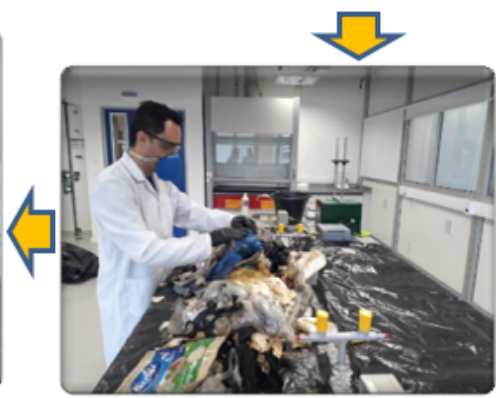

5. Bend spread

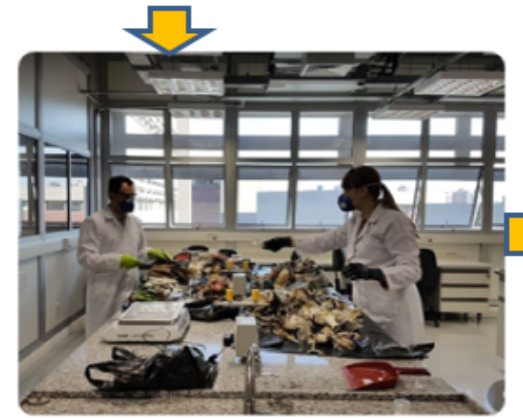

10. Spread and gravimeric analyses

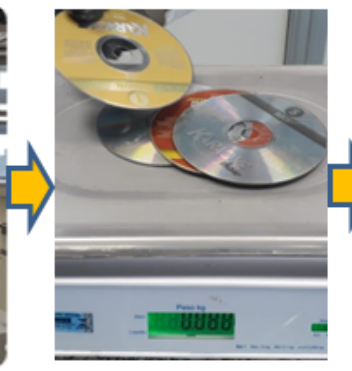

11. Gravimeric weighing

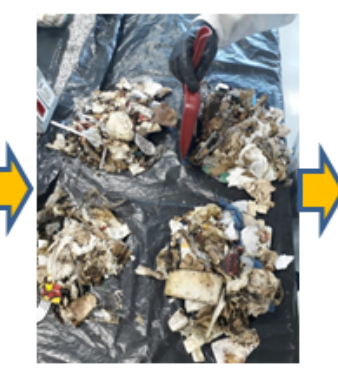

12. Quartering

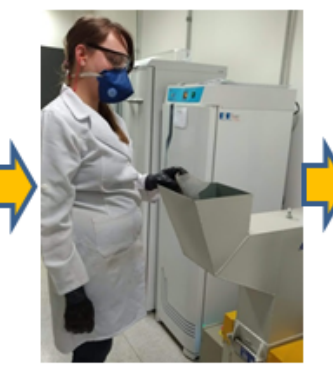

13. Shredding

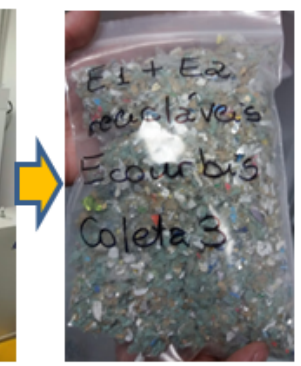

14. Samples prepared

Figure 2

MSW samplings preparation and analysis in the laboratory. 


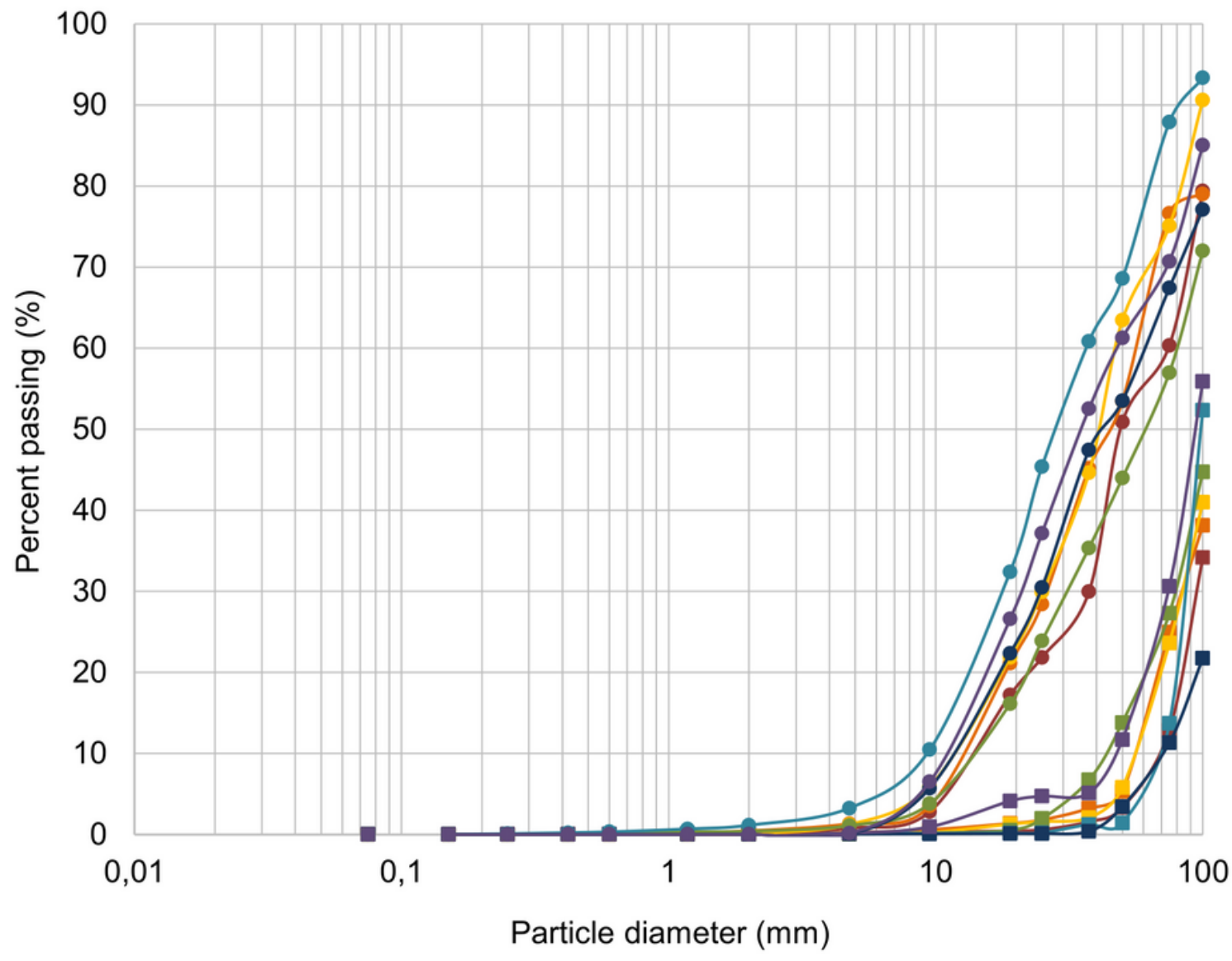

$\rightarrow$ Campaign 1 (I)

$\rightarrow-$ Campaign 2 (I)

- Campaign $3(\mathrm{I})$

-C-Campaign 4 (I)

-C-Campaign 5 (I)

$\rightarrow$ Campaign 6 (I)

- Campaign 7 (I)

$\multimap$ Campaign 1 (O)

$\longrightarrow$ Campaign 2 (O)

$\longrightarrow$ Campaign $3(\mathrm{O})$

$\longrightarrow$ Campaign 4 (O)

$\multimap$ Campaign 5 (O)

$\longrightarrow$ Campaign $6(\mathrm{O})$

$\longrightarrow$ Campaign $7(\mathrm{O})$

Figure 3

Grain size distribution curves of the MSW samples collected from MRF-Ecourbis, São Paulo (SP), Brazil.

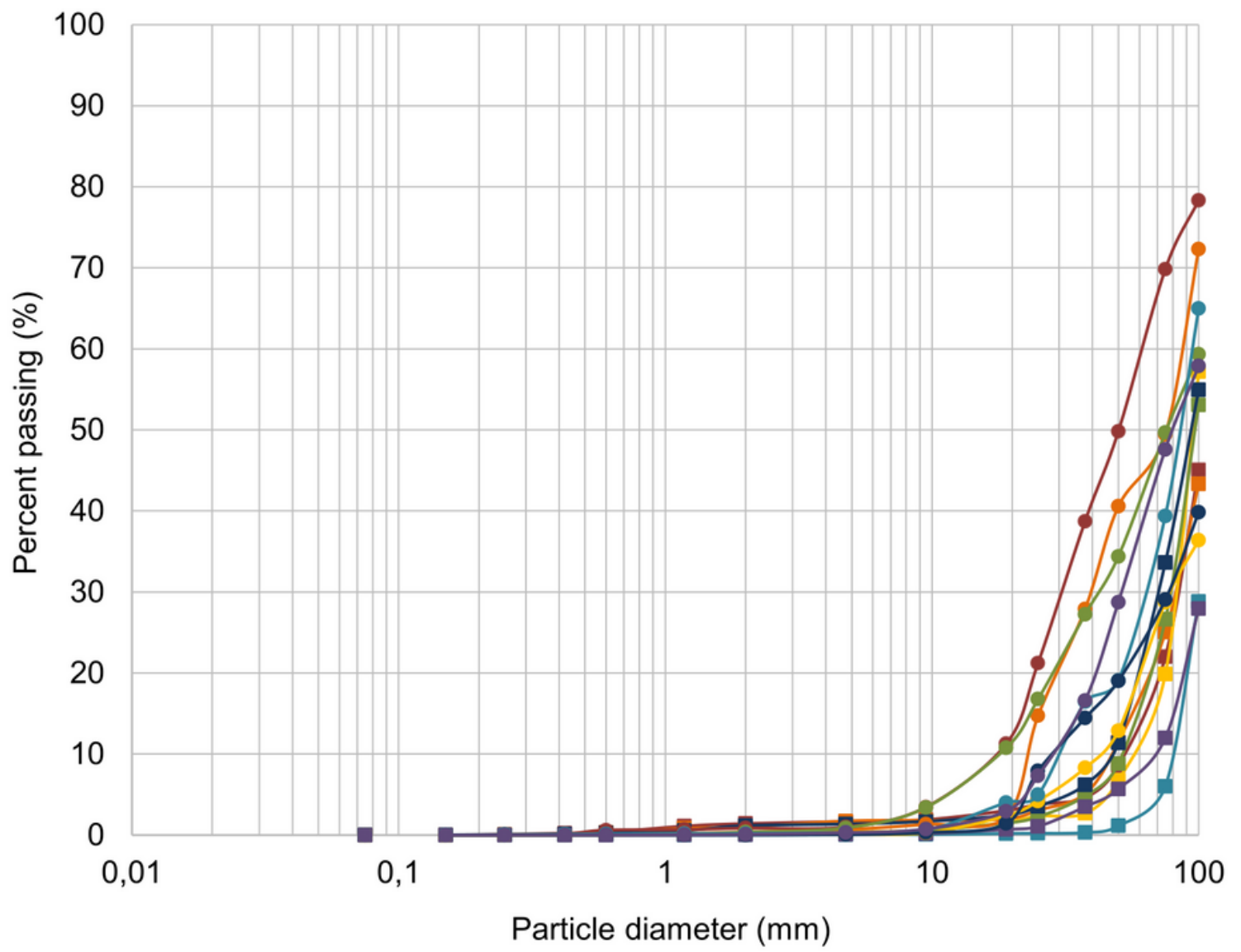

$\rightarrow-$ Campaign 1 (I)

-C-Campaign 2 (I)

- Campaign 3 (I)

-COmpaign 4 (I)

- Campaign 5 (I)

$\rightarrow$ Campaign 6 (I)

$\rightarrow$ Campaign 7 (I)

$\longrightarrow$ Campaign 1 (O)

$\longrightarrow$ Campaign 2 (O)

$\longrightarrow$ Campaign $3(\mathrm{O})$

$\longrightarrow$ Campaign 4 (O)

$\longrightarrow$ Campaign 5 (O)

$\longrightarrow$ Campaign $6(\mathrm{O})$

$\multimap$ Campaign $7(\mathrm{O})$

Particle diameter $(\mathrm{mm})$ 
Grain size distribution curves of the MSW samples collected from MRF-Loga, São Paulo (SP), Brazil.

$$
\begin{aligned}
& \longrightarrow \text { Campaign } 1(\mathrm{O}) \\
& \longrightarrow \text { Campaign } 6(\mathrm{O})
\end{aligned}
$$

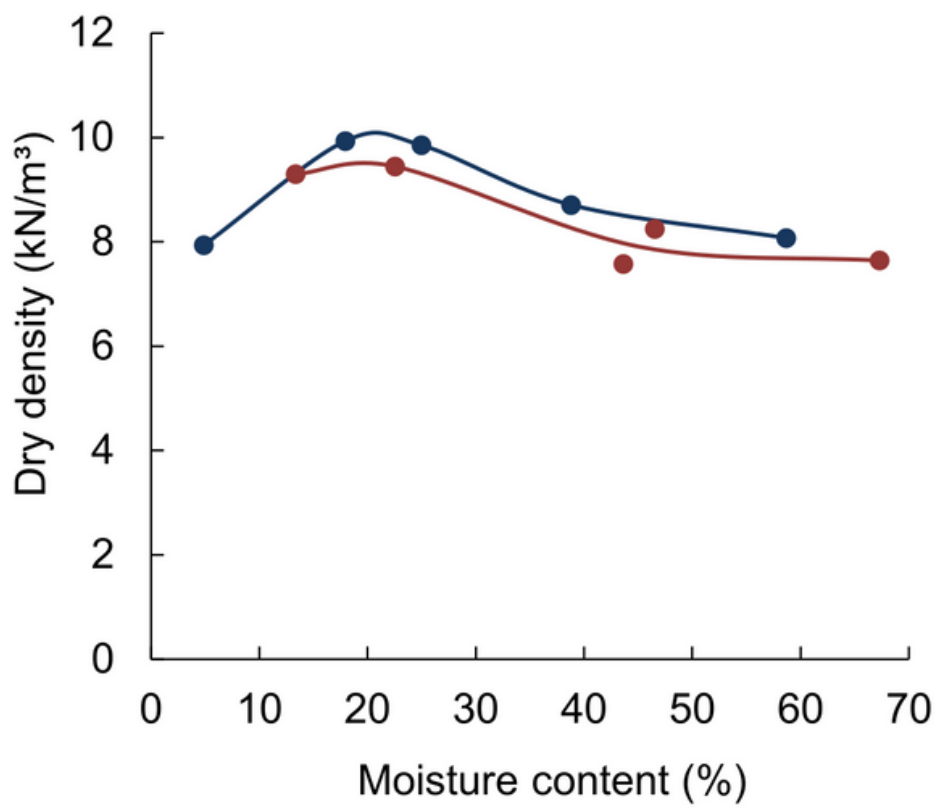

(a) MRF-Ecourbis

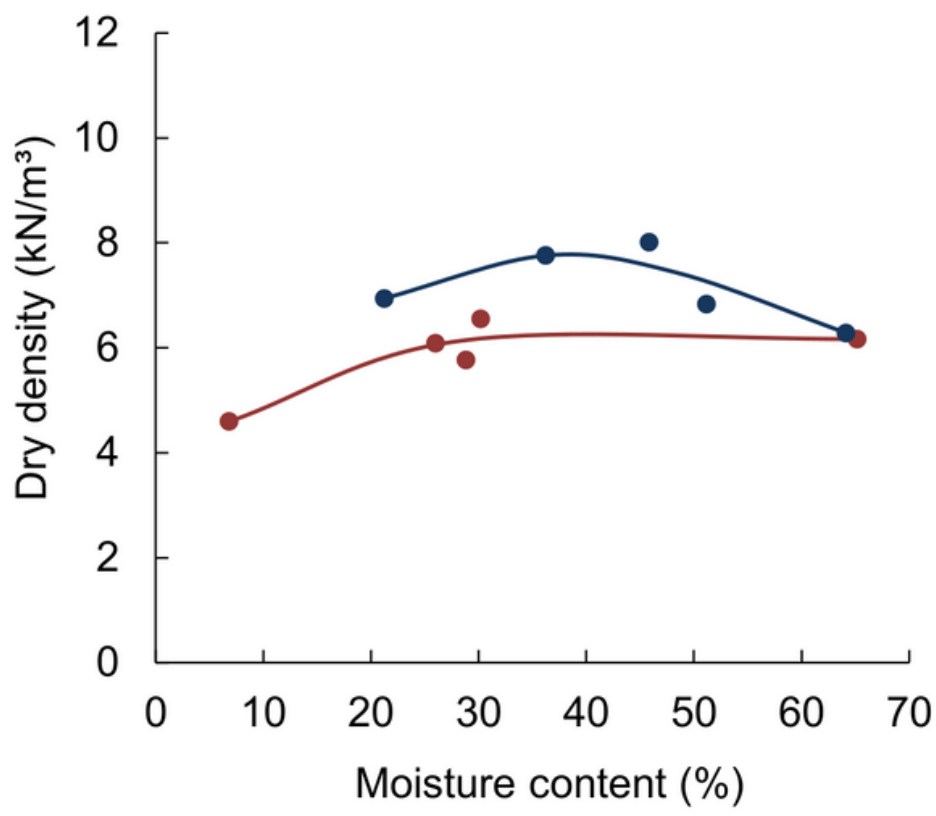

(b) MRF-Loga

Figure 5

Standard Proctor compaction curves obtained for shredded MSW samples from study MRFs in São Paulo city (SP), Brazil.

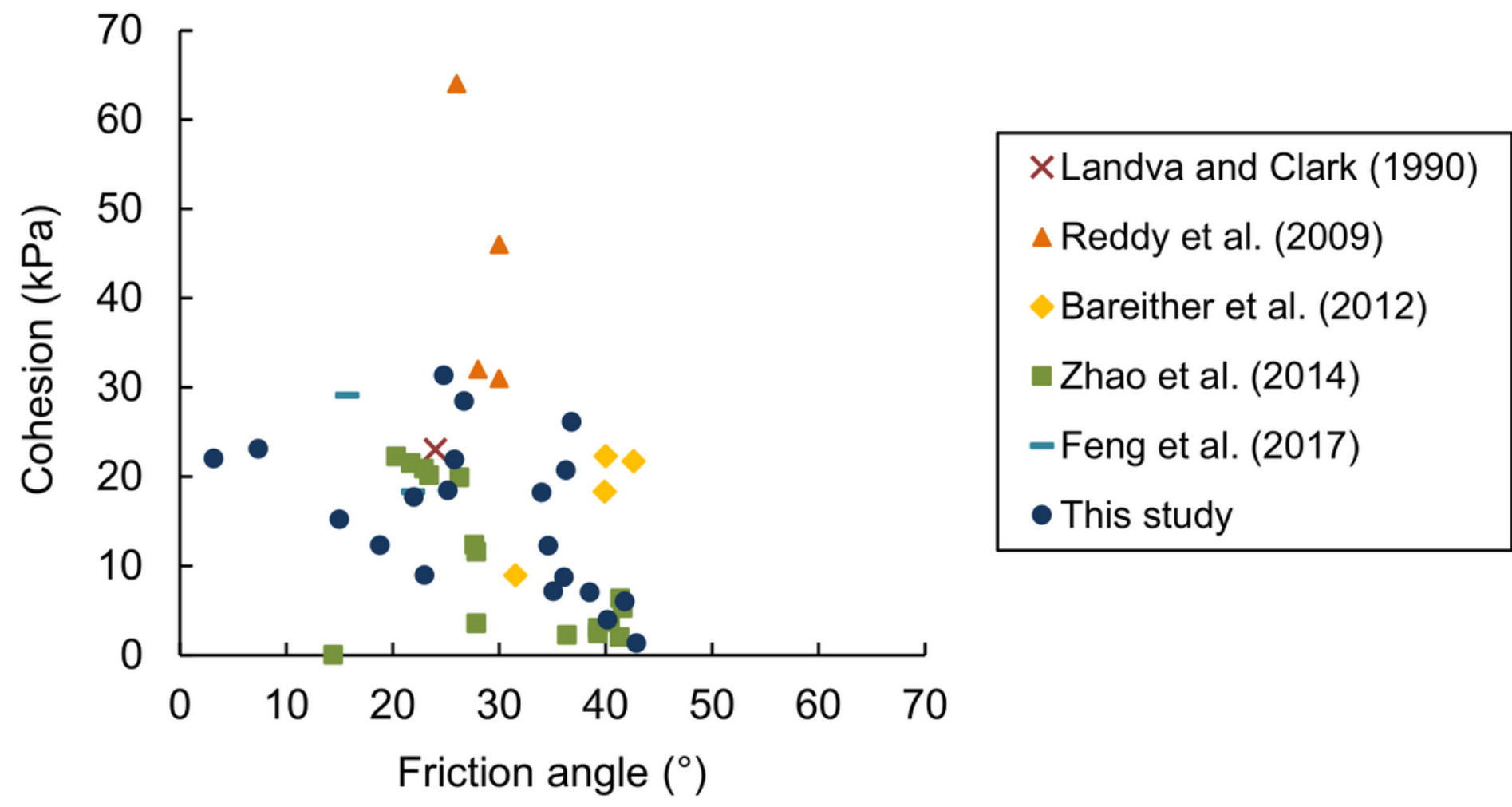

Figure 6 


\section{Supplementary Files}

This is a list of supplementary files associated with this preprint. Click to download.

- SupplMaterial.docx 